\title{
Ethnobotanical study of medicinal plants in the Hawassa Zuria District, Sidama zone, Southern Ethiopia
}

\author{
Banchiamlak Nigussie Tefera ${ }^{1,2}$ and Young-Dong Kim"
}

\begin{abstract}
Background: Ethiopia is one of the species-rich countries in the world and the center of origin with regard to the diversity of many plant species. Ethnobotanical studies are vital to investigate these diverse biological resources for medicinal purposes. The aim of this study was to document the indigenous knowledge of the Sidama people regarding the use of medicinal plants to treat human and livestock diseases in the Hawassa Zuria district of Southern Ethiopia.

Methods: A total of 150 informants (118 men and 32 women) were selected to collect ethnobotanical information from ten kebeles by means of a stratified purposive sampling method. Among the informants, 30 key informants were selected purposefully. Ethnobotanical data were collected through semi-structured interviews and group discussions and were analyzed by descriptive statistics, informant consensus factor (ICF), fidelity level (FL), and ranking methods.
\end{abstract}

Results: A total of 105 medicinal plants distributed across 52 families and 96 genera were collected. Fabaceae (11 species) was represented by the highest number of plant species, followed by Lamiaceae (7 species). Herbs (34\%) were the dominant growth habits, followed by trees (33\%). Leaves (56\%) were the dominant plant part used in the preparation of remedies, followed by fruit (15\%). The most common method of remedy preparation was grinding (39\%) followed by chewing and boiling (11\% each). Oral (74\%) was the major routes of administration, followed by dermal (20\%). There was a significant knowledge difference $(p<0.05)$ between social groups regarding the use of traditional medicinal plants. Insects and ectoparasites disease category (0.95) had higher informant consensus factor value followed by fever disease category (0.91). Eucalyptus globulus Labill. (100\%) had a higher fidelity level to treat stomachache, followed by Ensete ventricosum (Welw.) Cheesman. (87.27\%) to treat placenta delay. Ensete ventricosum (total score $=73$ ) was ranked highest as the most preferable medicinal plant for various purposes by local people, followed by Olea welwitschii (Knobl.) Gilg (total score $=72$ ).

Conclusion: The present study revealed the existence of indigenous knowledge of medicinal plants to treat human and livestock ailments. However, agricultural expansion, firewood collection, environmental degradation, and deforestation are the main threats to medicinal plants. Therefore, there should be mentoring for the local people in the study area to conserve their indigenous knowledge resources and prevent the extinction of medicinal plants.

Keywords: Medicinal plants, Traditional knowledge, Sidama people, Hawassa Zuria district, Ethiopia

\footnotetext{
* Correspondence: ydkim@hallym.ac.kr

'Department of Life Science and Multidisciplinary Genome Institute, Hallym

University, Chuncheon 24252, Republic of Korea

Full list of author information is available at the end of the article
}

(c) The Author(s). 2019 Open Access This article is distributed under the terms of the Creative Commons Attribution 4.0 International License (http://creativecommons.org/licenses/by/4.0/), which permits unrestricted use, distribution, and reproduction in any medium, provided you give appropriate credit to the original author(s) and the source, provide a link to the Creative Commons license, and indicate if changes were made. The Creative Commons Public Domain Dedication waiver (http://creativecommons.org/publicdomain/zero/1.0/) applies to the data made available in this article, unless otherwise stated. 


\section{Introduction}

Human beings have depended on nature for their simple requirements as being the source of medicines, shelters, food, fragrances, clothing, flavors, fertilizers, and means of transportation throughout their lives. Plants have been used for medicinal purposes since long before the prehistoric period [1].

Medicinal plants have made a significant contribution to the primary healthcare of people around the world. Population increases, inadequate supplies of drugs, the prohibitive cost of treatments, side effects of several synthetic drugs, and the development of drug resistance to infectious diseases have led to the increasing use of plant materials as a source of medicine for a wide variety of human ailments. Recently, the WHO estimated that $80 \%$ of people worldwide rely on herbal medicines for some aspects of their primary healthcare needs. According to the $\mathrm{WHO}$, around 21,000 plant species can potentially be used as medicinal plants [2].

Africa has rich resources of medicinal plant species. Ethiopia is believed to be home for about 6500 to 7000 species, with approximately $12 \%$ of these endemic [3]. In Ethiopia, approximately $80 \%$ of humans and $90 \%$ of the livestock population rely on traditional medicinal plants to cure different ailments [4] due to difficulties in accessing modern health facilities, the cultural acceptability of healers, and low cost of traditional medicine [5].

Southern Ethiopia is the main homeland of numerous ethnicities, containing more than 45 indigenous ethnic groups who speak at least 12 languages from four linguistic families [6]. The Sidama ethnic group (19.38\%) is the predominant group in the Southern Nations Nationalities and Peoples Region. They number about 4.8 million, of whom 3.9 are urban inhabitants. The main spoken language is Sidamegna (18\%) from the Cushitic linguistic family [7]. The daily lives of the Sidama peoples depend on agriculture. Ensete (Ensete ventricosum (Welw.) Cheesman.), also known locally as the wesse plant, is an important staple food. Coffee (Coffee Arabica L.) is the most important source of income, and the Sidama zone is the major contributor to coffee production. The Hawassa Zuria district is well known as a maize (Zea mays L.) growing district, with other crops also grown. The people raise cattle, and there is high value attached to livestock by the Sidama. The number of cattle owned is a good indicator of wealth, and popularity increases for farmers who own more cattle. The zone is also rich in water resources, which are underutilized.

Greater numbers of medicinal plants are found in the south and southwestern parts of Ethiopia due to the high biological and cultural diversity in these regions [3, 8]. Thus far, 1000 identified medicinal plant species have been reported among Ethiopian flora, but others remain not yet identified. There are approximately 887 medicinal plant species that are currently used by the Ethiopian people. Nearly 300 of these are frequently mentioned in many sources. The majority of medicinal plants are herbs, followed by shrubs and trees [9]. Most of the medicinal plant species are found in wild forests [10]. Over $40 \%$ of medicinal plant species have enormous socio-economic value in Ethiopia, and these require further investigations [11].

Ethnobotanical studies documented in Southern Ethiopia have studied the following: the Amaro district [12], the Benna Tsemay district [13], Burji district [14], Cheha district [15], Kembatta ethnic group [16], Konsso ethnicity [17], the Konta special woreda [18], the Lemo district [19], Maale and Ari [20], the Wolaita zone [21], the Wonago woreda [3], and the Wolaita zone [22]. However, there is still limited ethnobotanical documentation on medicinal plants and relatively few phytochemical analyses of documented medicinal plants. Ethnobotanical studies of medicinal plants conducted in the Sidama zone of southern Ethiopia have focused on the Boricha district [23], the Dale district [24], Hawassa city [25], the Bensa district [26], and Wondo genet [27].

The greater concentration of medicinal plants is found in the south and southwestern parts of the country in keeping with the concentration of biological and cultural diversity [28]. This indicates that there is high traditional medicinal plant knowledge in the southern part of Ethiopia, but the indigenous knowledge has not been systematically documented in the region. Particularly, there is no ethnobotanical study in the current study area of the Hawassa Zuria district. In addition, indigenous knowledge is disappearing due to a lack of written documents about medicinal plants, the deaths of tribal elders without the transfer of traditional skills to other members of the family, the migration of people due to social problems, urbanization and modernization, and the influence of modern medicine and exotic cultures. Therefore, the general research objective of this study was to collect, identify, and document medicinal plants and to collate the associated indigenous knowledge of the Sidama people with regard to how they treat various human and livestock ailments in the Hawassa Zuria district of the Sidama zone of Southern Ethiopia. This study was also conducted with the following specific objectives: (1) to measure and compare the indigenous knowledge of the Sidama people among social groups, (2) to discover traditional knowledge gaps and threats to medicinal plants, and (3) to provide baseline data for further phytomedicine and phytochemical studies.

\section{Material and methods}

\section{Description of the study area}

The Hawassa Zuria district $\left(07^{\circ} 01^{\prime} 54^{\prime \prime}\right.$ to $07^{\circ} 50^{\prime} 36^{\prime \prime}$ $\mathrm{N}$ and $38^{\circ} 15^{\prime} 39^{\prime \prime}$ to $38^{\circ} 25^{\prime} 43^{\prime \prime} \mathrm{E}$ ) is located $290 \mathrm{~km}$ 
from Addis Ababa in the Sidama zone, Southern Nations, Nationalities, and Peoples' Region (SNNPR) of Ethiopia, bordering Tula town in the east, Lake Hawassa in the north, the Oromia region in the west, and the Boricha district to the south (Fig. 1). This district has a total population of 124,472 , of whom 62,774 are men and 61,698 women [7]. The altitudinal range is $1700 \mathrm{~m}$ to 1850 m.a.s.l. The annual mean maximum and minimum temperatures are $30{ }^{\circ} \mathrm{C}$ and $17{ }^{\circ} \mathrm{C}$, respectively, and the mean annual rainfall is $1015 \mathrm{~mm}$. The size of the district is 22,643 ha and the dry zone accounts for $75 \%$ [29] and consists of 23 kebeles (farmers' associations).

The study was conducted in ten kebeles in the Hawassa Zuria district, SNNPR, from January to February of 2018. The ten kebeles selected were 'Dore Bafeno', 'Galo Argiso,' 'Jara Damowa,' 'Jara Dado', 'Tenkaka Unbulo,' 'Lebu Korem,' 'Jara Qerara,' 'Jara Hirnesa,' 'Jara Gelalcha', and 'Doyo Otilcho' (Fig. 1). The criteria for the selection of these study sites were the availability of traditional healers and recommendations from older people and local authorities.

\section{Sampling informants}

In total, 150 informants (118 men and 32 women) were selected among the Sidama people in the Hawassa Zuria district based on recommendations of elders, village administrators, and local guides. The ages of the informants were between 20 to 93 years. Snowball sampling was used and appointments were made prior to visiting the key informants.

\section{Ethnobotanical data collection}

The ethnobotanical study was collected from January to February of 2018. The techniques employed for data collection were group discussions, field observations, guided field walks, and a semi-structured questionnaire (see Additional file 1: Table S1). A semi-structured questionnaire that focused on determining the socioeconomic status of the participants was prepared, and

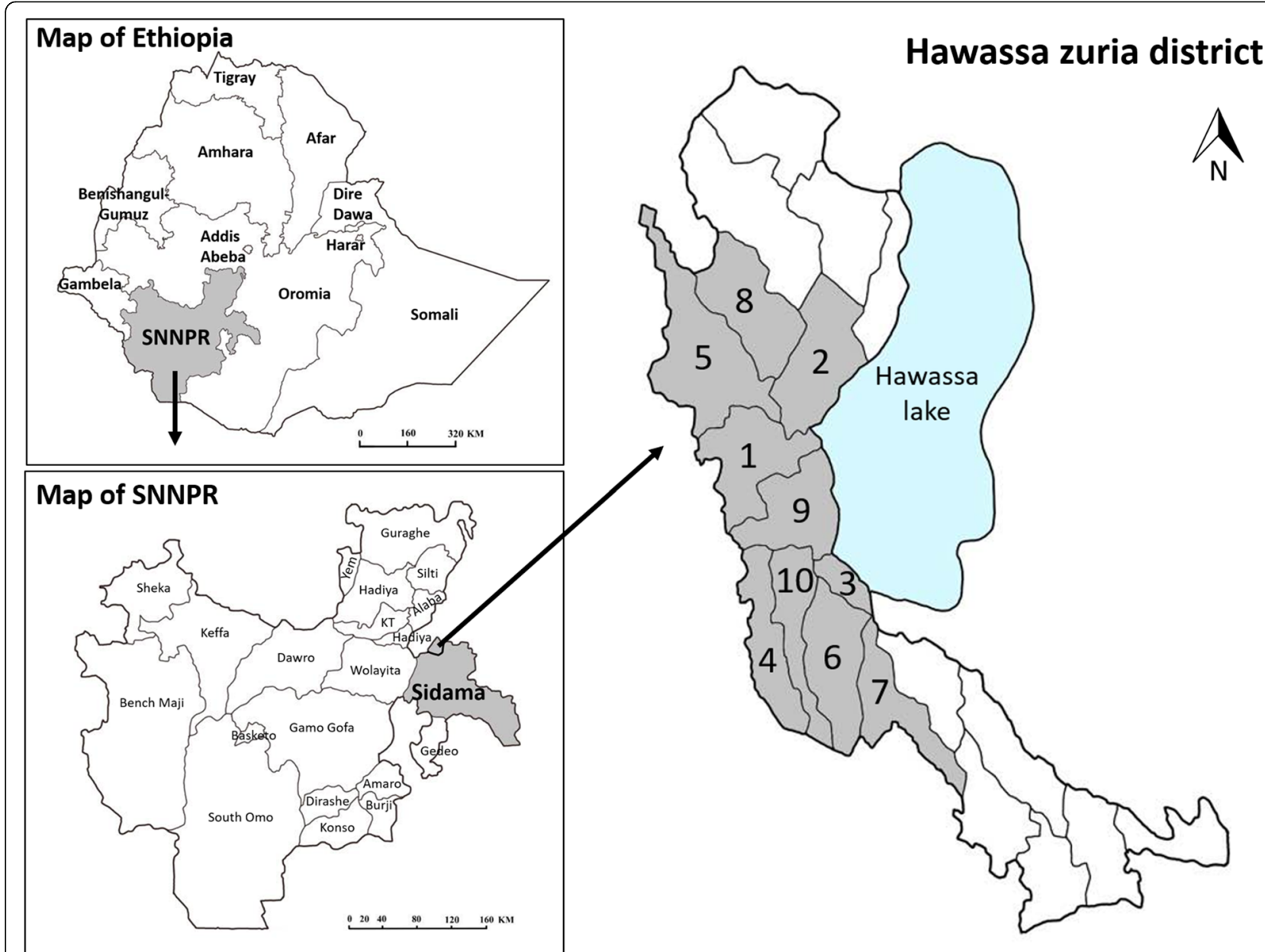

Fig. 1 Map of Hawassa Zuria district, Sidama zone, Southern Ethiopia. Study area kebeles: (1) Dore Bafeno, (2) Galo Argiso, (3) Jara Damowa, (4) Jaro Dado, (5) Lebu Korem, (6) Jara Hirnesa, (7) Tenkaka Umbulo, (8) Doyo Otilcho, (9) Jara Gelalcha, (10) Jara Qerara 
both informants and key informants were asked to present their knowledge about the medicinal plants they used to treat different ailments, the plant parts used, the method of preparation for the remedy, and details of the administration method and uses other than medicinal.

General and key informants were interviewed in the Sidama language with the assistance of a native translator.

\section{Plant specimen collection and identification}

Sample specimens of the plants cited for their medicinal use were collected, numbered, pressed, and dried for identification. Preliminary plant identification was performed in the field and results were reconfirmed at the National Herbarium of AAU. Identification of plant specimens was done using the Flora of Ethiopia and Eritrea book and also by comparisons with authenticated specimens with the help of experts at the National Herbarium of Addis Ababa University. Voucher specimens were deposited in the National Herbarium of Addis Ababa University.

\section{Data analysis}

Descriptive statistical methods, in this case percentage and frequency, were used to analyze and summarize the data on medicinal plants as well as their uses and associated knowledge, with MS Excel. According to disease categories in earlier work [30] and with some modification, the ailments were categorized into 14 categories based on the usage reports mentioned by the informants in the study area. The collected data were analyzed through the informant consensus factor and fidelity level [31, 32].

\section{Quantitative analysis}

The informant consensus factor was calculated using the formula ICF $=$ nur-nt/nur-1, where ICF denotes the informant consensus factor, nur is number of use citations, and nt is the number of species used [33]. ICF values range from 0.00 to 1.00 . High ICF values are obtained when only one or a few plant species are reported to be used by a high proportion of informants to treat a particular ailment. Low ICF values indicate that informants disagree over which plant to use. High ICF values can thus be used to find particularly important species in searches of bioactive compounds [34]. Fidelity level was used to analyze plant use with the formula $\mathrm{FL}=\mathrm{Np}$ / $N^{*} 100$, where Np denotes number of informants who reported the use of the plant to treat a particular disease and $N$ represents the number of informants who used the plants as a medicine [33].

Jaccard's coefficient of similarity (JCS) was calculated to evaluate medicinal plant species compositions and degrees of similarity among different areas. Similarity values were calculated between the present study area (Hawassa Zuria district) and other areas in similar agroecological zones which had been studied by other researchers in different parts of Ethiopia. The formula used to calculate the JCS is JCS $=c /(a+b+c)$, where JCS is Jaccard's coefficient of similarity, $a$ is the number of species found in habitat $\mathrm{A}, b$ is the number of species found only in habitat $\mathrm{B}$, and $c$ is the number of common species found in habitats A and B [35].

\section{Preference ranking}

Key informants were selected to assess the degree of effectiveness of medicinal plants when used to treat human and livestock diseases following Martin [36]. The medicinal plants believed to be most effective to treat an illness were given the highest value (5), while the least effective received the lowest values (1). The value of each species was summed and the rank for each species was determined based on the total score. This helped to indicate the most effective medicinal plants used by the community to treat diseases.

\section{Direct matrix ranking}

By following Cotton [37], direct matrix ranking was conducted in order to compare multipurpose medicinal plants commonly reported by informants. Based on the relative benefits obtained from each plant, eight multipurpose plant species were selected and seven use diversities of these plants were listed. Three key informants were chosen to assign use values for each attribute ( 5 = best, 4 = very good, 3 = good, 2 = less, 1 = least used). The use categories include food, fodder, house construction, farming utensils, material cleaning, cultural value, and firewood. Based on data obtained from the informants, the average use diversity value for each species was determined and the values for each species were finally summed and ranked.

\section{Results}

\section{Medicinal plants in the Hawassa Zuria district}

A total of 105 medicinal plant species belonging to 95 genera and 52 families were recorded in the study area (Table 1). Fabaceae (11 species) was represented by the highest number of plant species, followed by Lamiaceae (seven species), Cucurbitaceae (six species), Euphorbiaceae (five species), Solanaceae and Asteraceae (four species each) (Fig. 2). Anacardiaceae, Boraginaceae, Capparidiaceae, Malvaceae, Myrtaceae Poaceae, and Rutaceae were represented by three species each, whereas Celastraceae, Meliaceae, Moraceae, Musaceae, Rosaceae, Rubiaceae, and Verbenaceae were represented by two species each. Each of the remaining families was represented by one species (see Additional file 2: Table S2). 


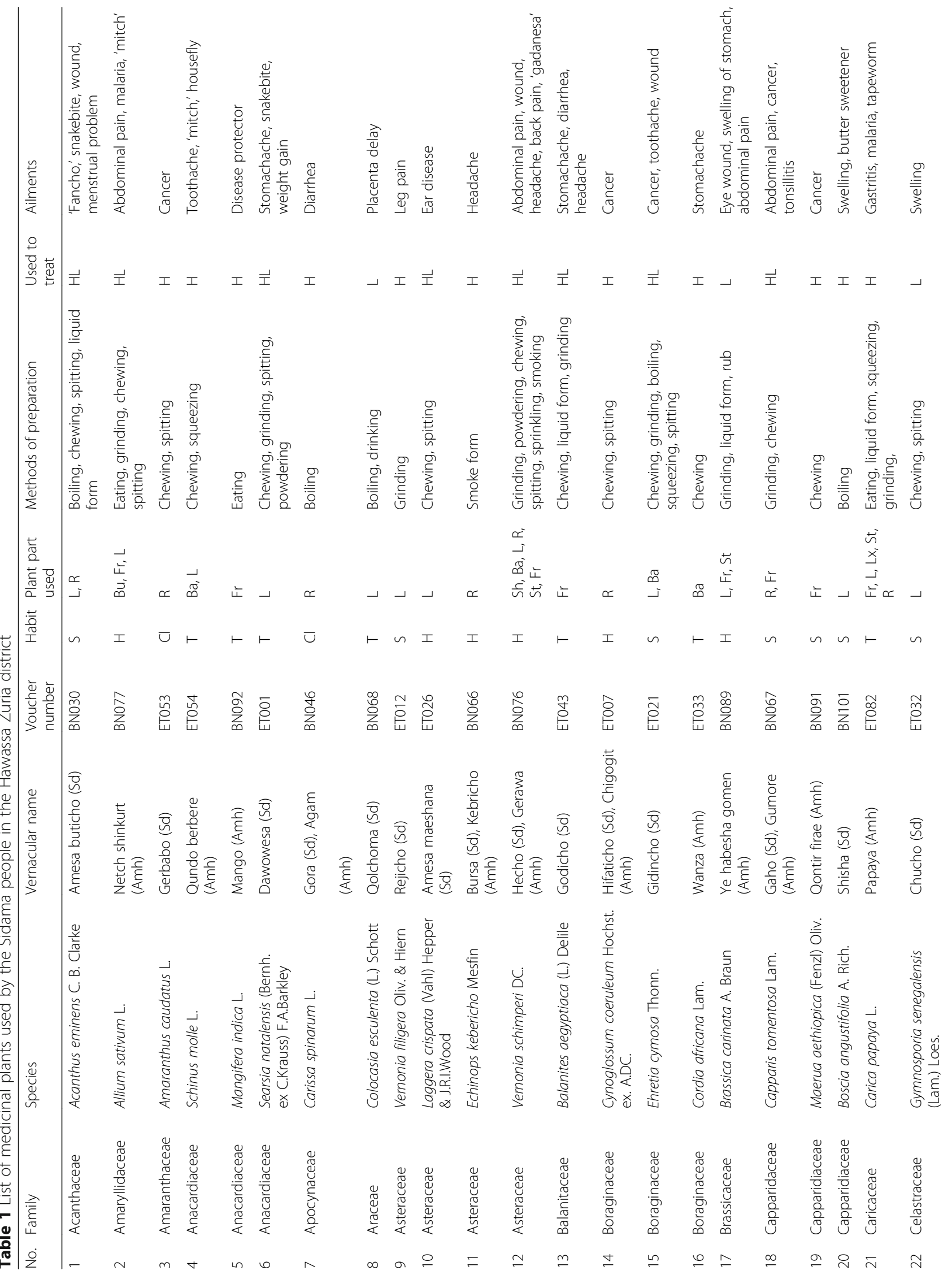




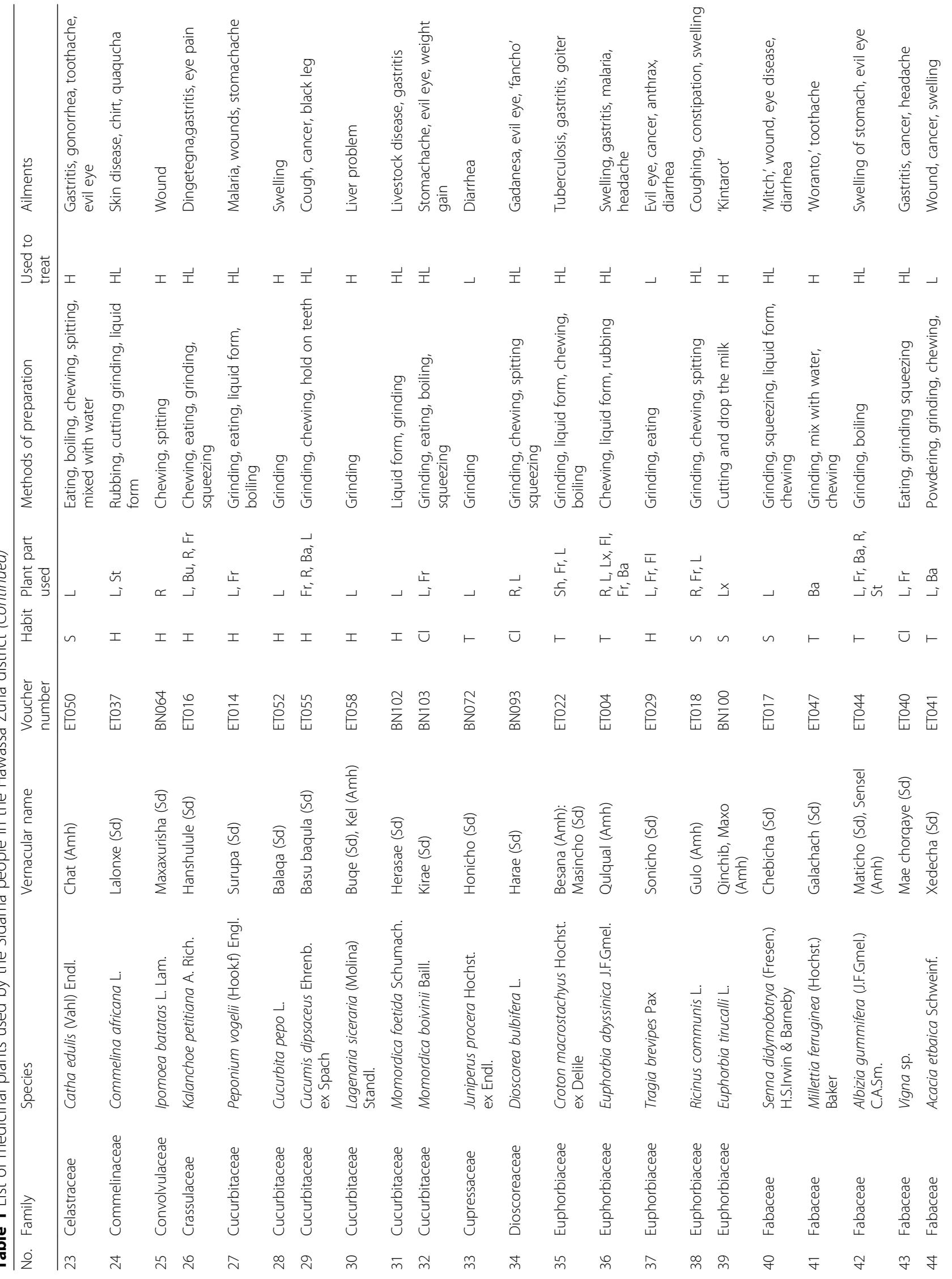




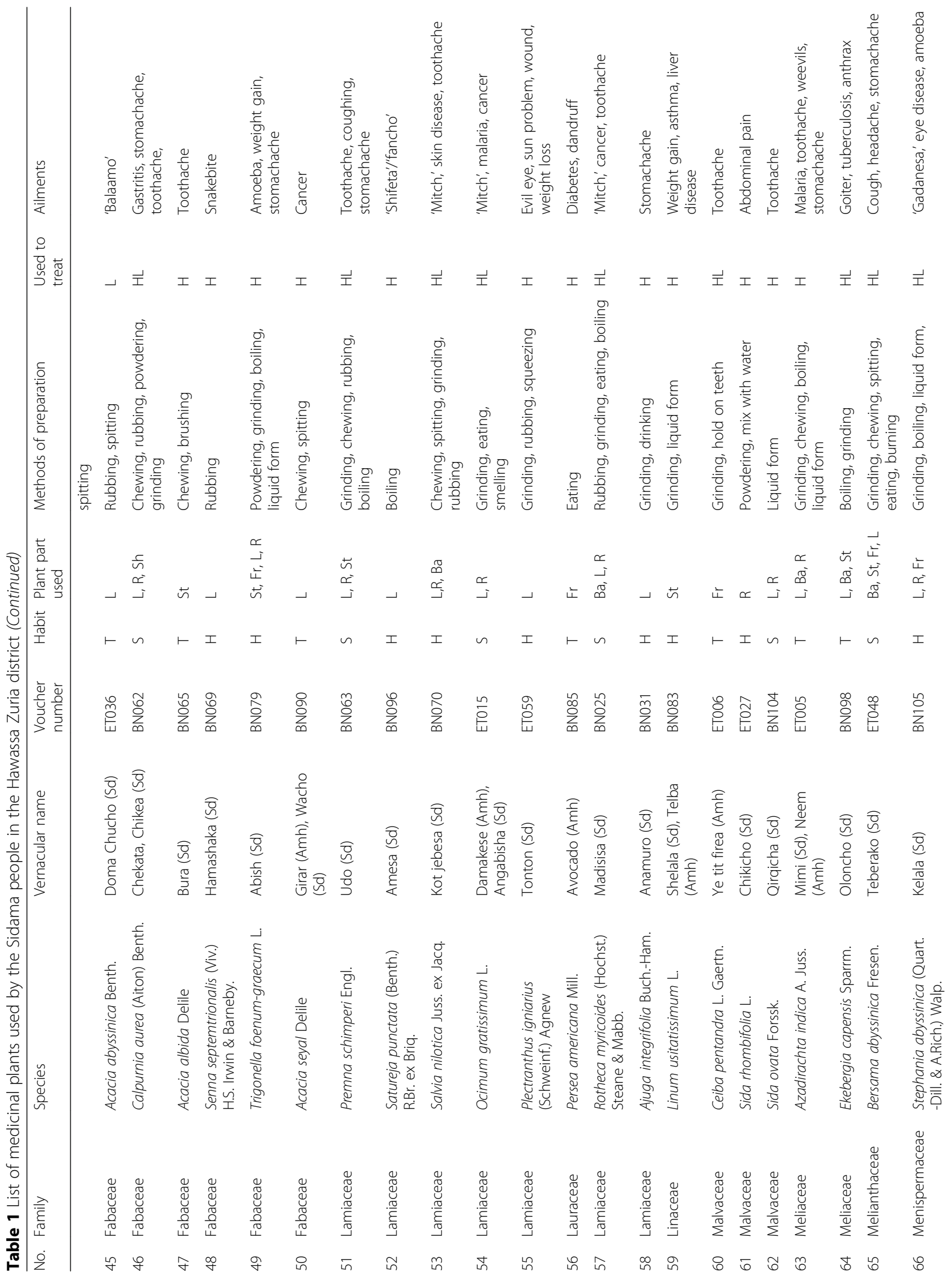




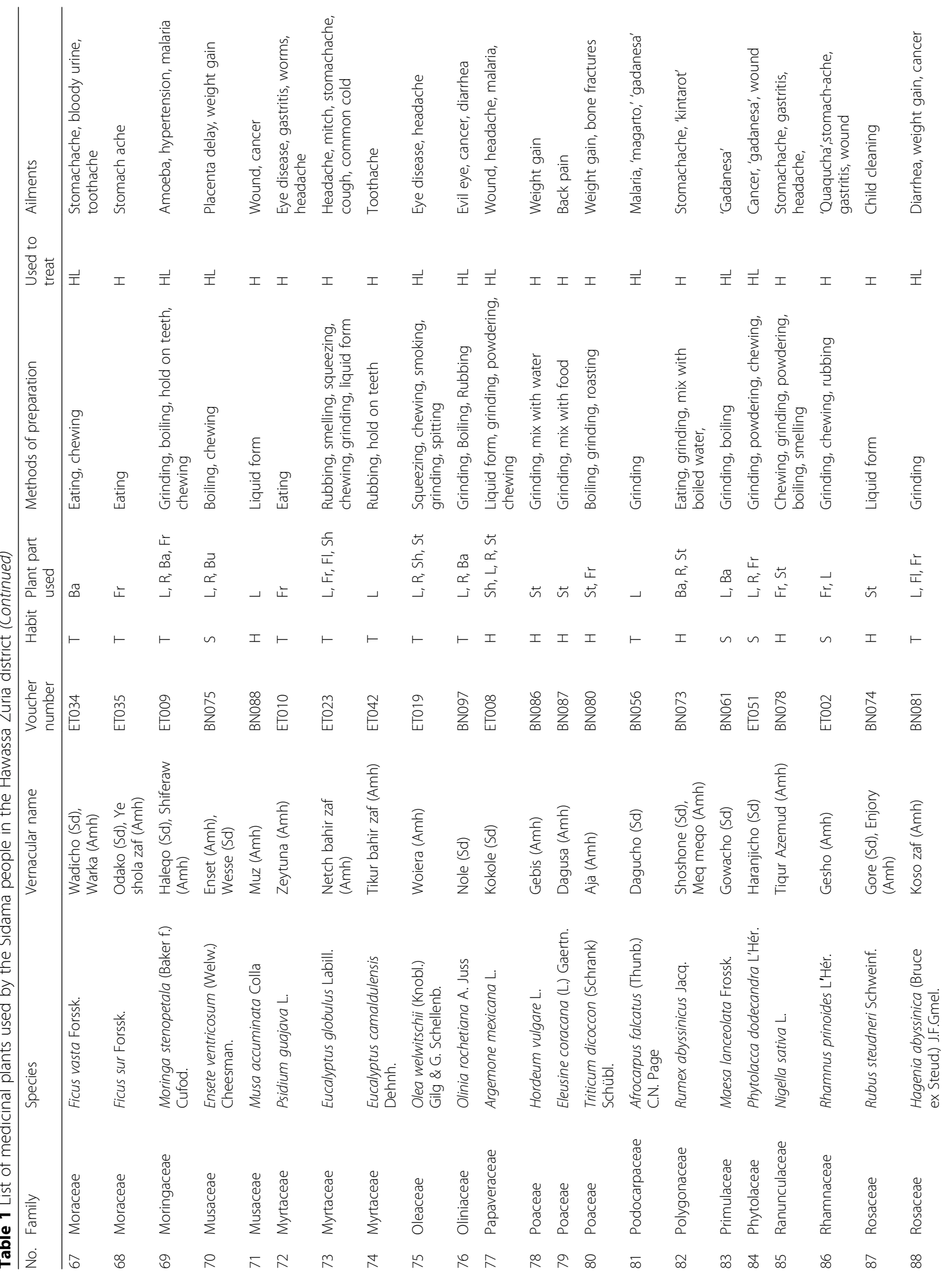




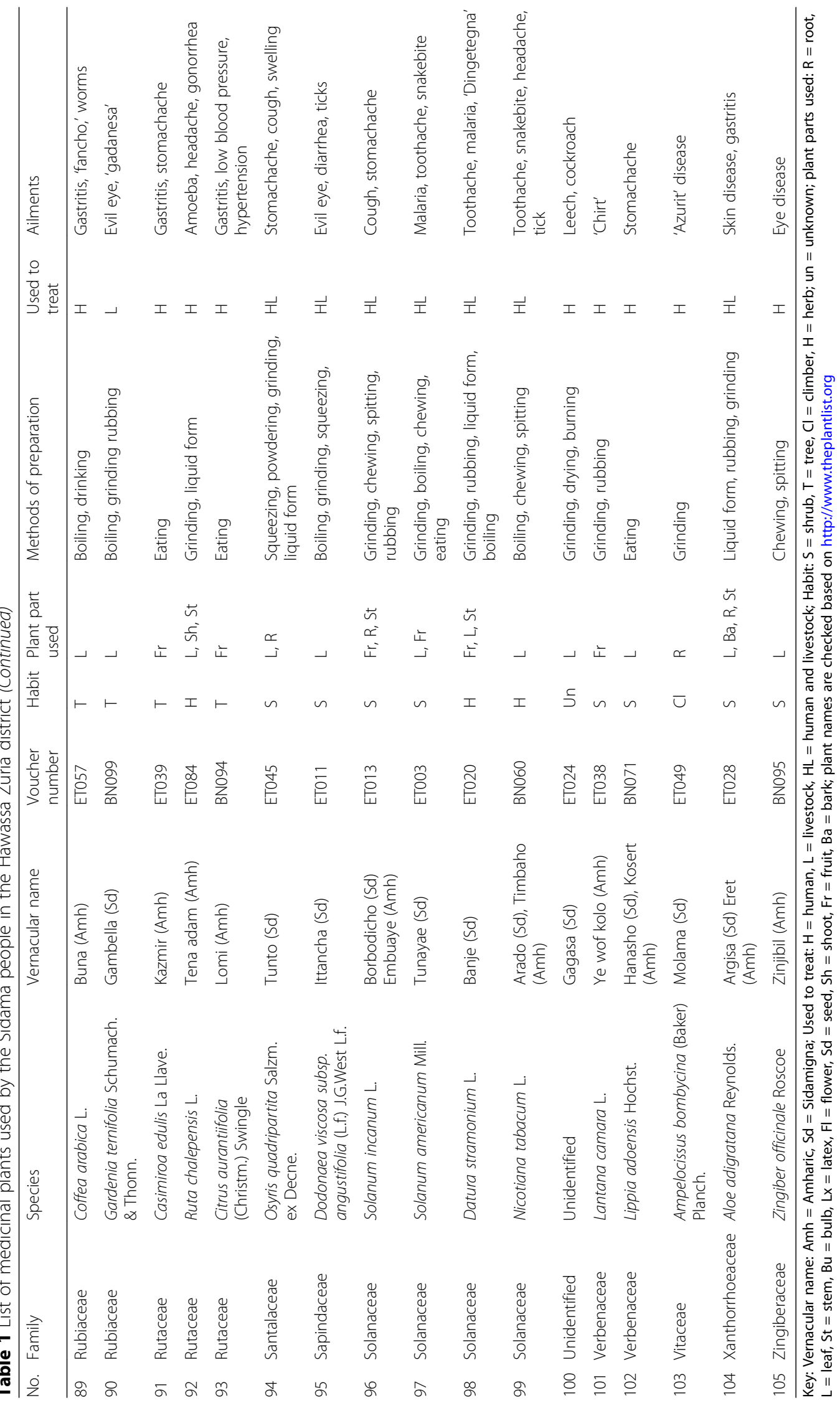




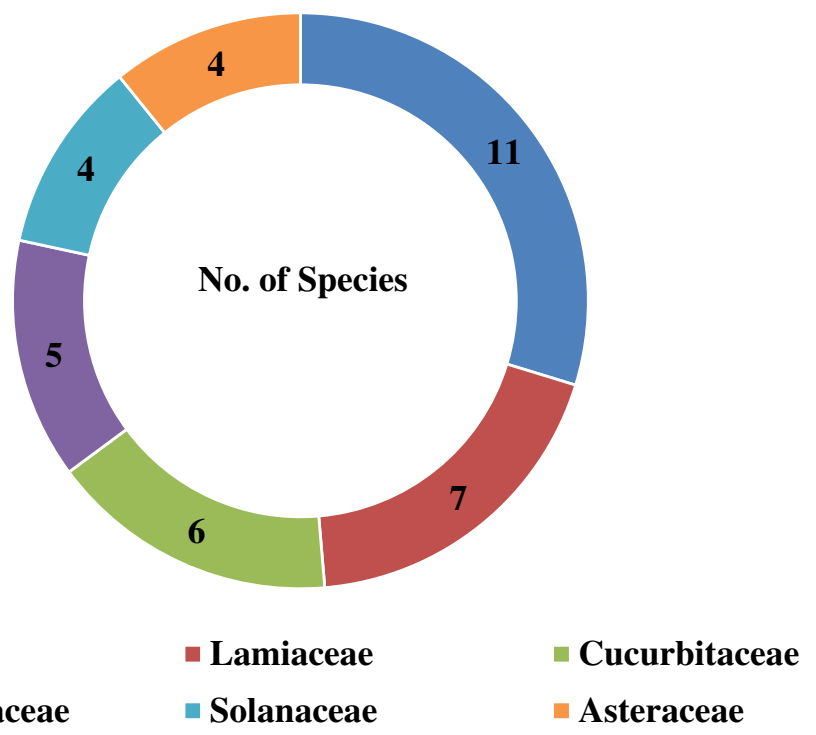

Fig. 2 Distribution of medicinal plant species across the different families

\section{Endemic medicinal plant species}

Among the documented medicinal plants in the study area, $71 \%$ of species were indigenous and $20 \%$ were introduced to Ethiopia. Five endemic plant species were recorded, representing $5 \%$ of all medicinal plant species in this study (Table 2).

\section{Therapeutic indications}

In the present study, $48 \%$ the reported medicinal plants were used only to treat human diseases, $45 \%$ were used for human and livestock ailments, and $8 \%$ were used only for livestock diseases. It was also found that $16 \%$ of the species were indicated to treat gastrointestinal ailments, followed by general and unspecified diseases at $14 \%$, dermatological infections/diseases at $10 \%$, and skeletomuscular system disorders, respiratory system diseases, and insect and ectoparasites diseases at $9 \%$ each (Fig. 3).

\section{Habits of growth and parts of plants used}

Medicinal plants were mainly harvested fresh (66\%), whereas the remaining (34\%) were used in a dry form. The results showed that medicinal plants used to treat human and livestock ailments consisted of 35 herbs (34\%), 34 trees (33\%), 29 shrubs (28\%), and six climbers (6\%) species. Thus, the most common form of medicinal plant in the study area was a herb, followed by trees and shrubs (Fig. 4).

The informants of the study area reported that leaves (56\%) were the dominant plant part used to prepare remedies, followed by fruits $(15 \%)$, roots $(12 \%)$, bark (5\%), seeds, stems and bulbs (4\%), shoot tips (2\%), and flowers and latex (1\%) (Fig. 5).

\section{Methods of preparation and routes of administration}

The most commonly used methods of remedy preparation were grinding (39\%), followed by chewing and boiling (11\%), eating (8\%), liquid form (6\%), spitting and rubbing (4\%), squeezing (3\%), powdering and smelling (2\%), and burning and holding on the teeth (1\%) (Fig. 6).

Medicinal plants were given via different routes of administration, such as oral, dermal, ocular, ear, external, and nasal. The most commonly used route was oral (74\%), followed by dermal (20\%). The remaining (2\%)

Table 2 Endemic plant species found in the study area

\begin{tabular}{llll}
\hline No. & Species & Vernacular name & Family \\
\hline 1 & Echinops kebericho Mesfin & Bursa (Sd) & Asteraceae \\
2 & Kalanchoe petitiana A. Rich. & Hanshulule (Sd) & Crassulaceae \\
3 & Millettia ferruginea (Hochst.) Baker & Galachach (Sd) & Fabaceae \\
4 & Lippia adoensis Hochst. & Hanasho (Sd), & Verbenaceae \\
5 & Aloe adigratana Reynolds & Argisa (Sd) & Xanthorrhoeaceae \\
\hline
\end{tabular}




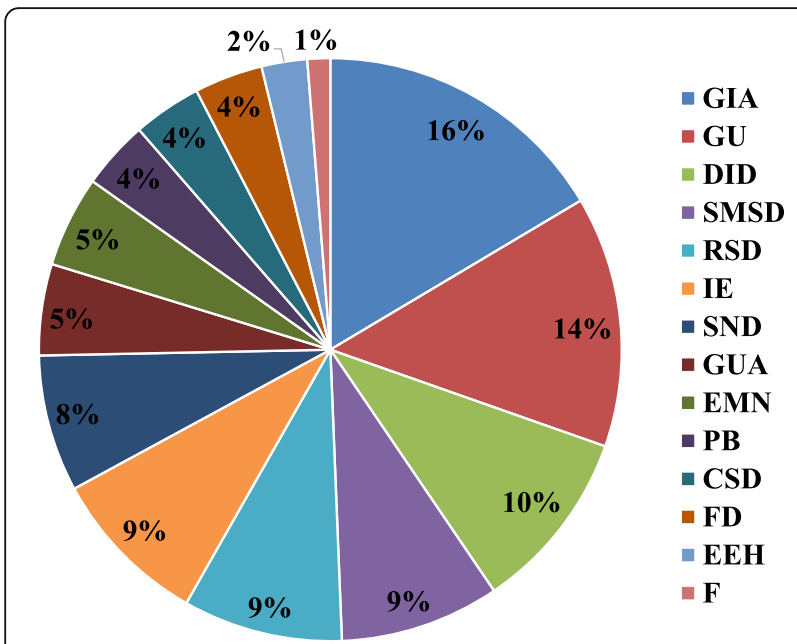

Fig. 3 Main therapeutic indications of diseases

types were applied through ocular, nasal, and external routes (Fig. 7).

\section{Medicinal plants used for treatment of human health problems}

A total of 50 species belonging to 46 genera and 30 families were recorded to treat human diseases. In the study area, 34 human ailments were identified to be treated by many medicinal plants (see Additional file 3: Table S3.). A single plant can treat a number of human ailments, and a single ailment can be treated by a number of

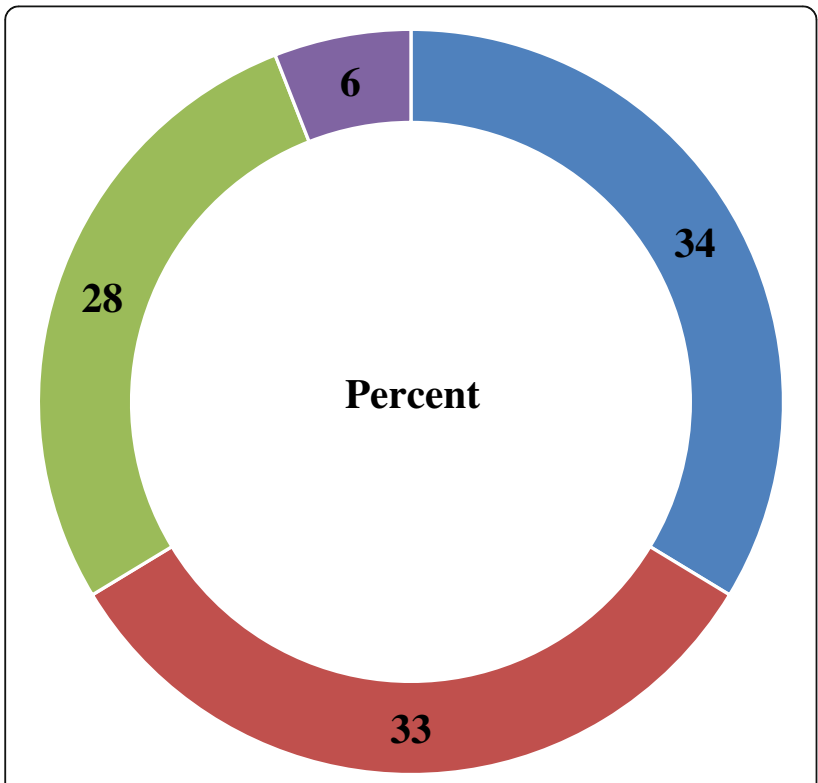

\#erb $\square$ Tree $\square$ Shrub $\square$ Climber

Fig. 4 Growth forms of the reported plant species plants. For instance, stomachache is a major disease and can be treated by 41 medicinal plants (Table 3 ).

\section{Medicinal plants used to treat livestock aliments}

A total of eight species belonging to seven genera and seven families were recorded as being used to treat livestock diseases. In this study, livestock diseases are treated with fewer plants compared to those used to treat human diseases. A total of 13 livestock diseases were treated by eight species of plants (Table 4). The most common diseases which affect animals in the study area were wounds, ticks, placenta delay, and swelling.

\section{Medicinal plants used to treat both human and livestock health ailments}

A total of 47 species belonging to 46 genera and 32 families were recorded as being used to treat both human and livestock diseases. In the Hawassa Zuria district, 22 types of human and livestock ailments were recorded (Table 5) and 47 medicinal plants were identified to treat both human and livestock ailments.

\section{Sociodemographic characteristics of the respondents}

One hundred fifty informants participated in the ethnobotanical survey of the Hawassa Zuria district. Of these, $118(78.6 \%)$ were men, $32(21.4 \%)$ were women, and 30 were key informants. The majority of respondents were more than 50 years old (42.4\%) and 56 informants ranged in age between 36 and 50 years (37.4\%). Thirty informants were between 20 and 35 years old (20\%). The majority of informants had attended elementary school (48\%) (Table 6). Seventy-six percent were farmers and $83 \%$ were followers of the protestant religion (see Additional file 4: Table S4).

Medicinal plant knowledge with respect to gender, age, and education

Significantly more $(p<0.05)$ medicinal plants were known by men than by women, by informants in the age group above 50 years compared to those aged between 20 and 35 years and between 36 and 50 years, among literate informants who attended elementary school than by illiterate informants (Table 7 ).

\section{Jaccard's coefficient of similarity}

The highest Jaccard's coefficient of similarity in the composition of medicinal plants was found between the study area and Wondo Genet district (15.5\%), whereas the degree of similarity was lower with Mana Angetu (8.96\%) (Table 8). Possible reasons for the similarity and differences between the study area and other areas may be the agroecological climatic conditions in the region. 


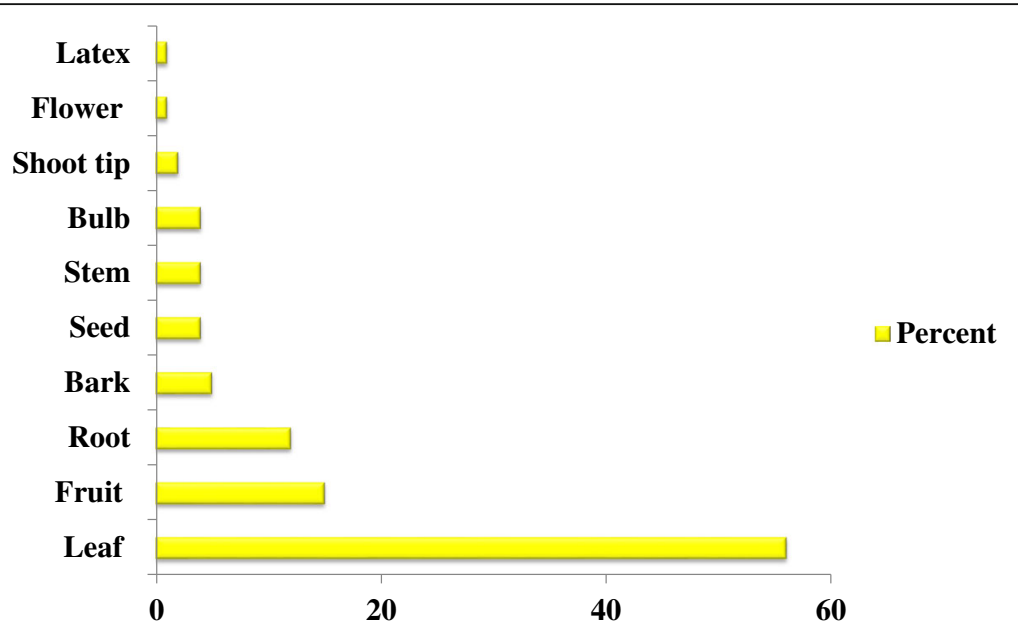

Fig. 5 Plant parts used in the study area

\section{Informant consensus factor}

The diseases in the study area were grouped into 14 disease categories based on the usage reports by the informants and the resemblance to the disease category. A total of 61 diseases treated by 105 plant species were documented in the study area. Among the disease categories, the categories with the highest informant consensus factor (ICF) values were insects and ectoparasites (0.95), followed by fever (0.91) and sensory neuron diseases (0.86) (Table 9). The medicinal plants that had higher ICF values were presumed to be more common and effective when used to treat a certain disease. However, fetal disease and the pregnancy-related category had a lower ICF value (0.59). Lower ICF values indicated that the informants disagreed on the taxa to be used as a treatment within the disease category. The highest plant use citation was found for gastrointestinal issues (418), followed by sensory neuron diseases (297) and then general and unspecified diseases (241).

\section{Fidelity level}

Eucalyptus globules (100\%) and Ensete ventricosum (87.27\%) were the two plant species with the highest fidelity levels. These were in the gastrointestinal ailment and fetal disease pregnancy-related categories, respectively, and were followed by Moringa stenopetala (81.69\%) and Catha edulis (74\%) correspondingly within the cardiovascular system disease and genito-urinary ailments categories. A higher fidelity level (FL) can imply that a particular plant purpose is preferred if informants mentioned it often. In contrast, the lowest fidelity level value was assigned to Dodonaea viscosa subsp. angustifolia (29.17\%), followed by Croton macrostachyus (31.18\%) from insects and ectoparasites and the skeletomuscular system

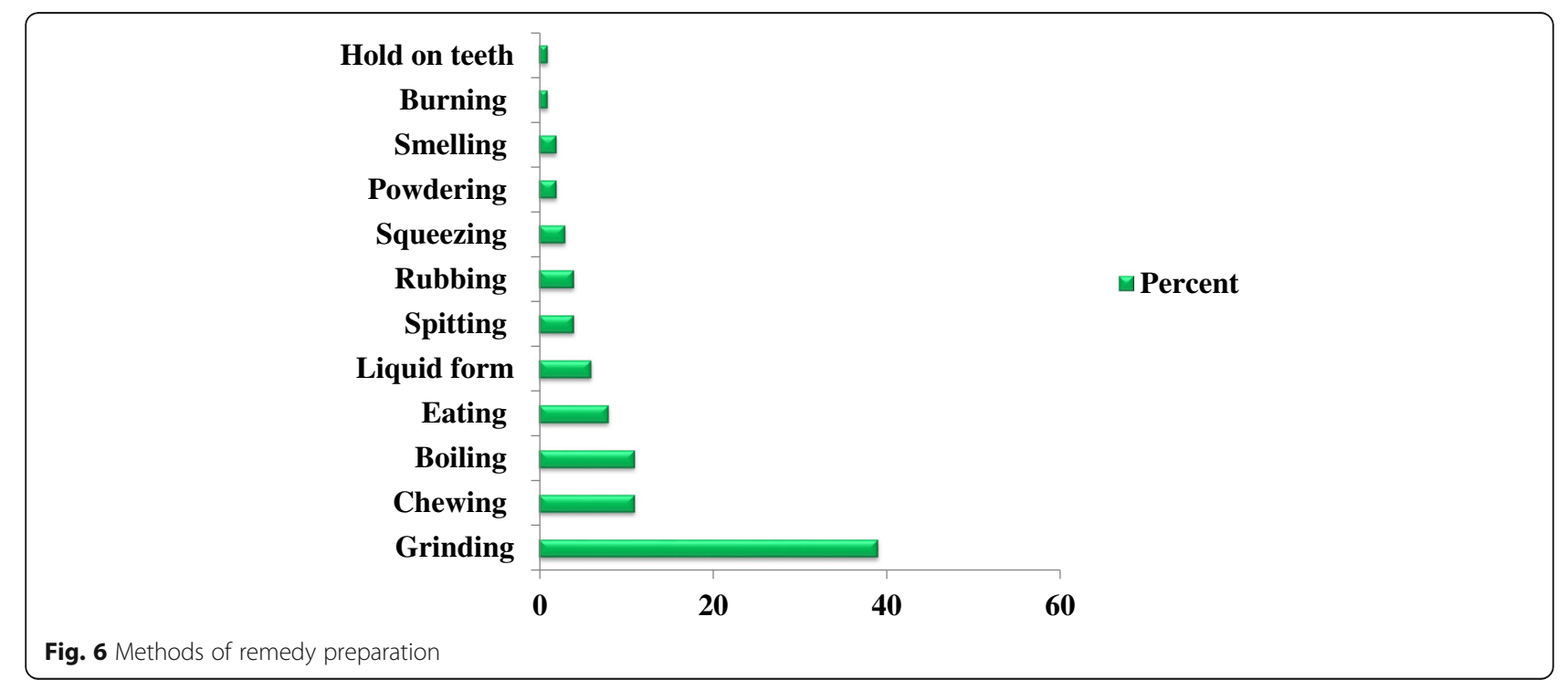




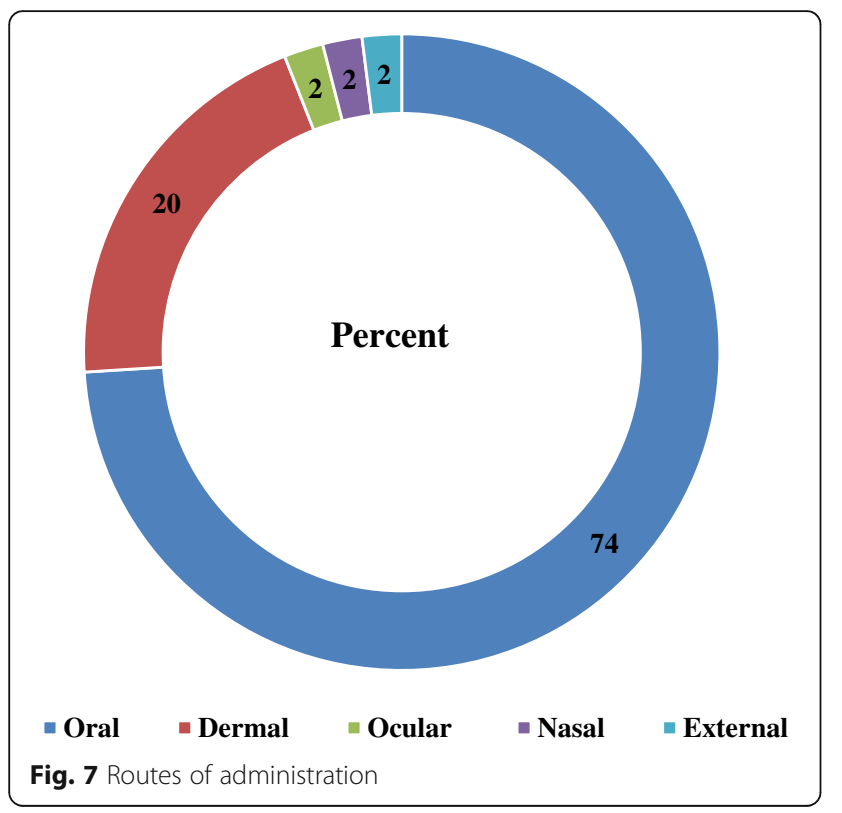

disorders category, respectively. A lower fidelity level implies that a particular plant purpose is not preferred (Table 10).

Table 3 Human ailments that can be treated by medicinal

\begin{tabular}{lll} 
plants & & \\
\hline No. & Human ailments & No. of medicinal plants \\
\hline 1 & Stomachache & 41 \\
2 & Headache & 28 \\
3 & Malaria & 18 \\
4 & Gastritis & 15 \\
5 & 'Mitch' & 14 \\
6 & Amoeba & 12 \\
7 & Goiter & 12 \\
8 & Tuberculosis & 11 \\
9 & Gonorrhea & 11 \\
10 & Urine problems & 10 \\
11 & 'Fancho'/shifeta' & 10 \\
12 & Liver disease & 10 \\
13 & 'Kintarot' & 9 \\
14 & 'Dingetegna'/Sudden illness & 9 \\
15 & Hypertension & 9 \\
16 & Toothache & 7 \\
17 & Skin disease & 6 \\
& Others & 70 \\
\hline & Total & 276 \\
\hline
\end{tabular}

Table 4 Livestock ailments that can be treated by medicinal plants

\begin{tabular}{lll}
\hline No. & Livestock ailments & No. of medicinal plants \\
\hline 1 & Wounds & 6 \\
2 & Ticks & 5 \\
3 & Swelling & 3 \\
4 & Anthrax & 2 \\
5 & Evil eye & 2 \\
6 & 'Gadanesa' & 2 \\
7 & Abdominal pain & 2 \\
8 & Bloody urine and shivering & 2 \\
9 & 'Lelit wof besheta' & 2 \\
10 & Black leg & 1 \\
11 & Rabies & 1 \\
12 & Leech & 2 \\
13 & Placenta delay & 1 \\
& Total & 31 \\
\hline
\end{tabular}

\section{Preference ranking}

Ten key informants were asked to compare seven medicinal plants based on their knowledge of medicinal plants for the treatment of stomach problems by assigning a score of five for the most effective medicinal plants and one for the least effective medicinal plants. Eucalyptus globulus Labill. was ranked as the most preferable medicinal plant for stomachache, followed by Nigella sativa L. (Table 11).

The output of the preference ranking indicated that Tragia brevipes Pax., Ricinus communis L., and Acacia etbaica Schweinf. were the most preferable medicinal plants for treating wound diseases in livestock (Table 12).

Table $\mathbf{5}$ Human and livestock ailments that can be treated by medicinal plants

\begin{tabular}{lll}
\hline No. & Human and livestock ailments & No. of medicinal plants \\
\hline 1 & Cancer & 19 \\
2 & Headache & 15 \\
3 & Coughing and sneezing & 14 \\
4 & Diarrhea & 14 \\
5 & Wound & 13 \\
6 & Eye pain & 13 \\
7 & Weight gain & 13 \\
8 & Toothache & 12 \\
9 & 'Dingetegna'/Sudden illness & 11 \\
10 & Worms & 10 \\
11 & Swelling & 10 \\
& Others & 62 \\
& Total & 207 \\
\hline
\end{tabular}


Table 6 Demographic characteristics of the informants

\begin{tabular}{lclllllll}
\hline Gender & Count & $\%$ & Age & Count & $\%$ & Educational status & Count & $\%$ \\
\hline Male & 118 & 78.6 & Young (20-35) & 30 & 20 & Illiterate & 59 & 39.4 \\
Female & 32 & 21.4 & Adult (36-50) & 56 & 37.4 & Basic & 4 \\
& & & Elder (>50) & 64 & 42.4 & Elementary (1-8th) & 72 \\
& & & & & Secondary (9-12th) & 12 \\
& & & & & Tertiary (Tech.) & 3 \\
\end{tabular}

According to the results, cancer was the most common disease challenging both humans and livestock in the Hawassa Zuria district. The preference ranking results showed that Cucumis dipsaceus Ehrenb. ex Spach was the medicinal plant preferred as a treatment for cancer both in human and livestock, followed by Rotheca myricoides (Hochst.) Steane \& Mabb. and Euphorbia abyssinica J.F.Gmel. (Table 13).

\section{Other uses of medicinal plants in the study area}

The majority of respondents reported that the medicinal plants can also be used as food, fodder, and as house construction materials in the study area (see Additional file 5: Table S5). In this case, 33\% of the medicinal plant species were reported to be used for food, the highest rate, followed by fodder (28\%), and house construction materials (26\%) (Fig. 8).

\section{Direct matrix ranking}

Key informants evaluated the functionality of multifunctional medicinal plants to the local people and indicated their scores for each medicinal plant (on a scale of 1 to 5). Eight medicinal plants were selected to be evaluated in seven usage categories. The output of the direct matrix analysis found Ensete ventricosum to be the preferred medicinal plant used for various purposes by the local people, followed by Olea welwitschii (Knobl.) Gilg \& G. Schellenb., and Dodonaea viscose subsp. angustifolia (Table 14).

Table 7 Comparison of the number of medicinal plants use report by different informant groups

\begin{tabular}{lllll}
\hline Parameter & Informant group & $N$ & Mean \pm SD & $p$ value \\
\hline Gender * & Women & 117 & $11.7 \pm 8.83$ & 0.000024 \\
& Men & 406 & $40.6 \pm 13.6$ & \\
Age * $^{*}$ & Young (20-35) & 106 & $10.6 \pm 8.77$ & 0.039038 \\
& Adult (36-50) & 189 & $18.9 \pm 11.9$ & \\
& Older ( $>50$ years) & 228 & $22.8 \pm 15.3$ & \\
Education * $^{*}$ & Illiterate & 205 & $20.5 \pm 12.5$ & 0.004907 \\
& Basic & 16 & $1.6 \pm 2.83$ & \\
& Elementary & 256 & $25.6 \pm 11.2$ & \\
& Secondary & 35 & $3.5 \pm 3.37$ & \\
& Tertiary & 11 & $1.1 \pm 1.79$ & \\
\hline
\end{tabular}

*Significant difference $(p<0.05)$ between the averages of paired categories

\section{Threats to medicinal plants}

Numerous factors are considered as threats to the medicinal plants in the study area. According to the responses from the key informants, the major threat to medicinal plants was agricultural expansion (30\%) followed by firewood collection (23\%) and environmental degradation (20\%) (Fig. 9).

\section{Discussion}

In this study, 105 medicinal plant species were identified for the treatment of human and livestock ailments distributed across 52 families and 95 genera. From the 52 plant families, Fabaceae (21\%) was the major contributing species, followed by Lamiaceae $(13 \%)$ and then Cucurbitaceae (12\%). Similarly, various studies in Ethiopia [25, 38-40] have reported Fabaceae as the most dominant medicinal plant family. In contrast, other studies found that Lamiaceae [18] and Euphorbiaceae [41] were dominant over others.

Among the documented medicinal plants, five endemic medicinal plant species were recorded. Identification of endemic species and current statuses is vital for the conservation of medicinal plants. The medicinal plants in the study area had diverse growth forms, in this case herbs (34\%), trees (33\%), shrubs (28\%), and climbers (6\%) were the dominant medicinal plants. Similarly, Lulekal et al. [38] reported that most medicinal plants were herbs in Ankober. Mesfin et al. [3] and Giday [9] also reported that the dominant medicinal plants were herbs. In contrast, the majority of medicinal plants were shrubs in the Wonago district [3]. Regassa [25] in Hawassa city indicated that the majority of the collected medicinal plants there were trees, followed by shrubs.

The results here showed that the local people of the Hawassa Zuria district use different parts of a medicinal plant to prepare remedies. Leaves were the most widely used part, making a contribution to the conservation of plants rather than harvesting the root part and/or whole plant. In the same way, Berhane [20] reported leaves as the predominant plant part used by the Maale and Ari ethnic communities. Ketema [42] also noted leaves were the most commonly used plant part in a study focusing on South Omo. The majority of medicinal plants were harvested for their leaves by the Sheko as well [9]. 
Table 8 Comparison of species found in the study area with those in other study areas

\begin{tabular}{|c|c|c|c|c|c|}
\hline Study areas & Species no. $(a$ or $b)$ & Common species $(c)$ & Jaccard's coefficient (sj) & $\%$ similarity & References \\
\hline Hawassa Zuria district & 105 & - & - & - & $\overline{\text { Study area }}$ \\
\hline Amaro district & 56 & 22 & 0.12 & 12.0 & {$[12]$} \\
\hline Wondo Genet district & 85 & 35 & 0.15 & 15.5 & {$[27]$} \\
\hline Wonago district & 155 & 26 & 0.09 & 9.09 & {$[3]$} \\
\hline Mana Angetu & 230 & 33 & 0.08 & 8.96 & [49] \\
\hline
\end{tabular}

$a$ is the number of species which is found in habitat $A, b$ is the number of species found only in habitat $B$, and $c$ is the number of common species found in habitats $A$ and $B$

However, the most frequently used plant parts were roots in the Hadiya zone [43] and in Benna Tsemaye [13].

The local people in the Hawassa Zuria district use different remedy preparation methods depending on the type of disease to be treated. Cutting, tying, spraying, roasting, soaking, hanging, brushing, squeezing, powdering, spitting, and holding on the teeth were some of the preparation methods used to treat human and livestock diseases. The most commonly used method of remedy preparation was grinding (39\%), followed by chewing and boiling (11\%). Elsewhere in Ethiopia, similar findings were reported $[13,44]$ with regard to the most commonly used methods of remedy preparation. These were crushing, followed by chewing, boiling, eating, and in liquid form.

The prepared remedies were administered in different ways. Some of the routes of administrations were via the oral, dermal, and ocular routes and via the ear, externally, and through the nasal passage. The majority of the remedies were administered done so orally $(74 \%)$ followed by the dermal (20\%) and ocular (2\%) routes. Similar findings were also documented in different parts of Ethiopia. The majority of medicinal plants were administered orally in Endrta [45]. Assegid [13] reported that the majority of plants were used in oral applications in the Tsemay district. Sintayehu [27] found that prepared remedies were widely administered orally in Wondo Genet.

In the Hawassa Zuria district, 34 human, 13 livestock, and 22 ailments of both humans and livestock were recorded. This indicated that the people of the district suffered from many ailments as compared to those in other areas, such as in the Wonago district [3] and the Bench district [9]. Moreover, a single human ailment

Table 9 Informant consensus factors for categorized diseases

\begin{tabular}{|c|c|c|c|c|c|}
\hline No. & $\begin{array}{l}\text { Category name and } \\
\text { abbreviations }\end{array}$ & Reported diseases & $\begin{array}{l}\text { No. of } \\
\text { usage } \\
\text { report }\end{array}$ & $\begin{array}{l}\text { No. of } \\
\text { taxa }\end{array}$ & ICF \\
\hline 1 & Gastrointestinal ailments (GIA) & $\begin{array}{l}\text { Diarrhea, abdominal pain, swelling of stomach, stomachache, tape worms, amoeba, } \\
\text { cholera, gastritis, vomiting, constipation, liver disease, toothache, indigestion }\end{array}$ & 418 & 101 & 0.76 \\
\hline 2 & $\begin{array}{l}\text { Dermatological infections/diseases } \\
\text { (DID) }\end{array}$ & $\begin{array}{l}\text { Wound, chirt, quaqucha, 'bugunji,' itching, skin disease, bijajo (hand wound), } \\
\text { dandruff }\end{array}$ & 132 & 28 & 0.79 \\
\hline 3 & $\begin{array}{l}\text { Skeletomuscular system disorders } \\
\text { (SMSD) }\end{array}$ & Leg pain, leg swelling, back pain, bone fracture, anthrax, swelling, black leg & 67 & 18 & 0.74 \\
\hline 4 & Respiratory systems diseases (RSD) & Tuberculosis, tonsillitis, coughing, sneezing, common cold, cold, and asthma & 81 & 27 & 0.68 \\
\hline 5 & Genito-urinary ailments (GUA) & Gonorrhea (STD), 'kintarot,' urine problem, kidney disease & 69 & 22 & 0.69 \\
\hline 6 & Poisonous bites (PB) & Rabies, Snake bite and Spider poisoning & 25 & 8 & 0.71 \\
\hline 7 & $\begin{array}{l}\text { Cardiovascular system diseases } \\
\text { (CSD) }\end{array}$ & Hypertension, heart disease, low blood pressure & 20 & 7 & 0.68 \\
\hline 8 & $\begin{array}{l}\text { Endocrine/metabolic/nutritional } \\
\text { (EMN) }\end{array}$ & Diabetes, weight loss, goiter, weight gain & 124 & 30 & 0.76 \\
\hline 9 & Sensory neuron disease (SND) & Cancer, tetanus, headache, brain pain, 'azurit,' and typhoid & 297 & 41 & 0.86 \\
\hline 10 & Fetal disease pregnancy related (FD) & Abortion, fontanelle closure and placenta delay & 18 & 8 & 0.59 \\
\hline 11 & Ear and Eye health (EEH) & Ear disease and eye pain & 73 & 14 & 0.82 \\
\hline 12 & Fever $(F)$ & Malaria & 79 & 8 & 0.91 \\
\hline 13 & General and unspecified (GU) & $\begin{array}{l}\text { Mitch, dingetegna (Wugat, Kurtimat), evil eye, sun problem, Lelit wof disease, } \\
\text { Fancho/Shifeta, woranto, kuwashakor, balaamo, magarto, gadanesa }\end{array}$ & 241 & 61 & 0.75 \\
\hline 14 & Insects and ectoparasites (IE) & Cockroach, weevils, honeybee, house fly, corn worm, ticks and leech & 164 & 8 & 0.95 \\
\hline
\end{tabular}


Table 10 Relative healing potential levels of 14 cited medicinal plants used against human and livestock ailments

\begin{tabular}{|c|c|c|c|c|c|}
\hline No. & Frequently used species & Particular disease & IP & $\mathrm{IU}$ & FL (\%) \\
\hline 1 & Eucalyptus globulus & Stomachache & 30 & 30 & 100 \\
\hline 2 & Rhamnus prinoides & Skin disease & 9 & 14 & 64 \\
\hline 3 & Croton macrostachyus & Bone fracture & 29 & 93 & 31.18 \\
\hline 4 & Aloe adigratana & Coughing & 28 & 44 & 63.64 \\
\hline 5 & Catha edulis & Kintarot & 17 & 23 & 74 \\
\hline 6 & Moringa stenopetala & Hypertension & 89 & 109 & 81.69 \\
\hline 7 & Cucurbita pepo & Weight gain & 2 & 4 & 50 \\
\hline 8 & Cucumis dipsaceus & Cancer & 68 & 108 & 62.96 \\
\hline 9 & Ensete ventricosum & Placenta delay & 48 & 55 & 87.27 \\
\hline 10 & Peponium vogelii & Malaria & 28 & 73 & 38.36 \\
\hline 11 & Vernonia schimperi & Mitch & 25 & 62 & 40.32 \\
\hline 12 & Dodonaea viscosa subsp. angustifolia & Ticks & 14 & 48 & 29.17 \\
\hline 13 & Acacia etbaica & Wounds & 10 & 16 & 62.5 \\
\hline 14 & Ricinus communis & Cancer & 3 & 6 & 50 \\
\hline 15 & Rotheca myricoides & Headache & 43 & 95 & 45.26 \\
\hline 16 & Nicotiana tabacum & Toothache & 49 & 88 & 55.68 \\
\hline
\end{tabular}

was found to be treatable by several medicinal plants. This is in agreement with the findings of earlier studies $[27,45]$ that found single ailments to be treated by several medicinal plants. The present study found that $16 \%$ of medicinal plants were used to treat gastrointestinal ailments, with slightly lower rates for general and unspecified diseases (14\%). Similarly, among the Sheko, $16.9 \%$ of medicinal plants were used to treat gastrointestinal complaints [9]. The highest proportions of Meinit and Dek Island medicinal plants were used to treat gastrointestinal complaints [46, 47].

The present study indicated that men, older, and literate people who attend elementary school have more medicinal plant knowledge as compared to women, younger, and illiterate people. The reason for the high traditional knowledge of men and older people could be due to the influence of modernization and a lack of interest among the younger generations. Similar findings

Table 11 Preference ranking of medicinal plants used to treat stomachache in humans

\begin{tabular}{|c|c|c|c|c|c|c|c|c|c|c|c|c|}
\hline \multirow[t]{2}{*}{ Species } & \multicolumn{10}{|c|}{ Informants } & \multirow{2}{*}{$\begin{array}{l}\text { Total } \\
\text { score }\end{array}$} & \multirow[t]{2}{*}{ Rank } \\
\hline & 11 & 12 & 13 & 14 & 15 & 16 & 17 & 18 & 19 & 110 & & \\
\hline Ruta chalepensis & 4 & 3 & 4 & 5 & 4 & 5 & 2 & 3 & 2 & 3 & 35 & 5 \\
\hline Casimiroa edulis & 3 & 4 & 5 & 4 & 5 & 5 & 5 & 5 & 4 & 4 & 44 & 3 \\
\hline Eucalyptus globulus & 5 & 5 & 5 & 5 & 5 & 5 & 5 & 5 & 5 & 5 & 50 & 1 \\
\hline Azadirachta indica & 2 & 3 & 2 & 2 & 3 & 4 & 3 & 4 & 3 & 4 & 30 & 6 \\
\hline Rhamnus prinoides & 4 & 4 & 5 & 3 & 3 & 5 & 5 & 4 & 5 & 5 & 43 & 4 \\
\hline Nigella sativa & 5 & 4 & 4 & 5 & 5 & 5 & 5 & 5 & 5 & 5 & 48 & 2 \\
\hline Sida rhombifolia & 1 & 2 & 2 & 3 & 3 & 2 & 2 & 1 & 1 & 2 & 19 & 7 \\
\hline
\end{tabular}

also indicated that there are significance differences in traditional knowledge among different communities in Ethiopia [40, 48]. Unlike other studies, the current study indicated that literate people who attend elementary school reported a higher number of medicinal plants as compared to those who are illiterate.

Jaccard's coefficient of similarity indicated that there was some similarity in the composition of medicinal plants between the study area and the Wondo Genet district [27], whereas less similarity was found with regard to the Mana Angetu district [49]. This may stem from the agroclimatic conditions of the study area.

The category with the highest ICF values was fever (malaria), followed by insects and ectoparasites diseases. The highest plant use citation was found for gastrointestinal ailments, followed by sensory neuron diseases. Similarly, gastrointestinal disorders and parasite infections were the most commonly treated diseases on the Zegie peninsula [50].

The highest fidelity levels were found for gastrointestinal ailments in this study in all cases. Eucalyptus globulus Labill. (100\%) scored the highest fidelity level value. Similarly, Reta [25] reported that gonorrhea, wounds,

Table 12 Preference ranking of medicinal plants used to treat wounds in livestock

\begin{tabular}{|c|c|c|c|c|c|c|c|c|c|c|c|c|}
\hline \multirow[t]{2}{*}{ Species } & \multicolumn{10}{|c|}{ Informants } & \multirow{2}{*}{$\begin{array}{l}\text { Total } \\
\text { score }\end{array}$} & \multirow[t]{2}{*}{ Rank } \\
\hline & 11 & 12 & 13 & 14 & 15 & 16 & 17 & 18 & 19 & 110 & & \\
\hline Tragia brevipes & 5 & 4 & 4 & 5 & 3 & 4 & 4 & 4 & 5 & 5 & 43 & 1 \\
\hline Ricinus communis & 3 & 3 & 4 & 4 & 3 & 3 & 4 & 2 & 5 & 4 & 35 & 2 \\
\hline Acacia etbaica & 2 & 3 & 4 & 3 & 4 & 3 & 2 & 1 & 4 & 3 & 29 & 3 \\
\hline
\end{tabular}


Table 13 Preference ranking of medicinal plants used to treat cancer in both humans and livestock

\begin{tabular}{|c|c|c|c|c|c|c|c|c|c|c|c|c|}
\hline \multirow[t]{2}{*}{ Species } & \multicolumn{10}{|c|}{ Informants } & \multirow{2}{*}{$\begin{array}{l}\text { Total } \\
\text { score }\end{array}$} & \multirow[t]{2}{*}{ Rank } \\
\hline & 11 & 12 & 13 & 14 & 15 & 16 & 17 & 18 & 19 & 110 & & \\
\hline Olinia rochetiana & 5 & 3 & 3 & 4 & 5 & 4 & 4 & 3 & 4 & 4 & 39 & 4 \\
\hline Euphorbia abyssinica & 4 & 4 & 5 & 5 & 5 & 4 & 3 & 4 & 4 & 4 & 42 & 3 \\
\hline Rotheca myricoides & 5 & 5 & 4 & 3 & 5 & 5 & 5 & 5 & 5 & 5 & 47 & 2 \\
\hline Cucumis dipsaceus & 5 & 5 & 5 & 5 & 5 & 5 & 5 & 5 & 5 & 5 & 50 & 1 \\
\hline Dodonaea viscose subsp. angustifolia & 3 & 4 & 3 & 5 & 4 & 3 & 3 & 4 & 3 & 4 & 36 & 6 \\
\hline Vernonia schimperi & 3 & 3 & 2 & 4 & 3 & 2 & 3 & 2 & 3 & 2 & 27 & 7 \\
\hline Bersama abyssinica & 5 & 4 & 3 & 3 & 3 & 4 & 3 & 5 & 4 & 3 & 37 & 5 \\
\hline
\end{tabular}

and stomachache had high degrees of ICF and that malaria showed the highest FL in Hawassa city. Teferi [39] indicated that diarrhea and malaria were the most frequently reported diseases among the Benta ethnic group.

The output of the preference ranking indicated that Eucalyptus globulus, Nigella sativa L., and Casimiroa edulis La Llave. were the most commonly preferred medicinal plants as treatment for stomachache in human in the Hawassa Zuria district. Similar findings for South Omo showed that the highest numbers of plant species were reported to treat abdominal or stomach disorders [42]. Cucumis dipsaceus Ehrenb. ex Spach, Rotheca myricoides (Hochst.) Steane \& Mabb., and Euphorbia abyssinica J.F.Gmel were ranked as the most preferable medicinal plants to treat cancer in both humans and livestock.

According to the direct matrix ranking results, Ensete ventricosum ranked first as the most preferred medicinal plant used for various purposes by the local people. The second and third most preferable medicinal plants were Olea welwitschii (Knobl.) Gilg \& G. Schellenb. and Dodonaea viscose subsp. angustifolia, respectively. However, Prunus africanus is the most preferred medicinal plant for various use in Hadiya zone [43]. In the present study, Ensete ventricosum was used as a type of food, as fodder, in house construction, and for robe making. It also had cultural and spiritual value. Olea welwitschii was reportedly used mainly for purposes related to house construction, material cleaning, incense, spiritual value, firewood, and cultural value. However, the overexploitation of medicinal plants for other purposes can affect the availability and conservation of medicinal plants for their primary purpose.

According to the responses from key informants, the main causes of the loss of medicinal plants in the study area were agriculture expansion, firewood collection, environmental degradation, deforestation, construction, and charcoal creation. Other research on threats to medicinal plants in Dale [24], the Benna Tsemay district [13], the Mana Angetu district [49], Wondo Genet [27], Amaro woreda [51], and Wonago woreda [3] indicated findings similar to those here.

Other factors related to the loss of indigenous knowledge about medicinal plants were the secrecy of traditional knowledge practiced by elders in the tribe, a weak transfer system for indigenous knowledge, and the influence of modernization. Similarly, other findings [10, 27, 52-55] reported that there is an aura of top secrecy in

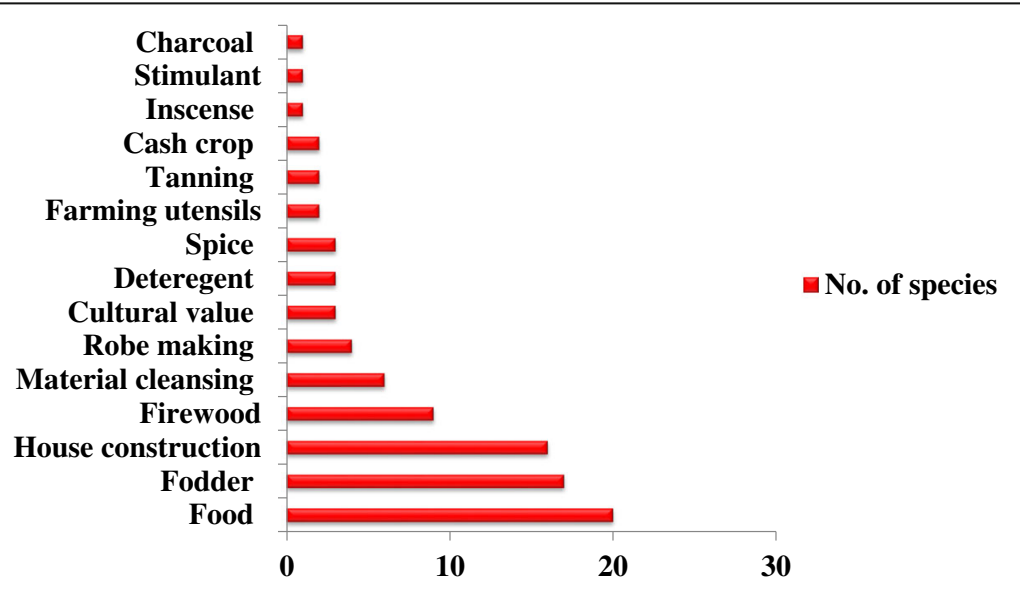

Fig. 8 Use categories and number of plant species 
Table 14 Direct matrix ranking of medicinal plants by informants (I1--13) based on usage category values

\begin{tabular}{|c|c|c|c|c|c|c|c|c|c|c|c|c|c|c|c|c|c|c|c|c|c|c|c|}
\hline \multirow[t]{2}{*}{ Plant species } & \multicolumn{3}{|c|}{ Food } & \multicolumn{3}{|c|}{$\begin{array}{l}\text { Cultural } \\
\text { value }\end{array}$} & \multicolumn{3}{|c|}{$\begin{array}{l}\text { Farming } \\
\text { utensils }\end{array}$} & \multicolumn{3}{|c|}{$\begin{array}{l}\text { House } \\
\text { construction }\end{array}$} & \multicolumn{3}{|c|}{ Firewood } & \multicolumn{3}{|c|}{ Fodder } & \multicolumn{3}{|c|}{$\begin{array}{l}\text { Material } \\
\text { cleaning }\end{array}$} & \multirow[t]{2}{*}{ Total } & \multirow[t]{2}{*}{ Rank } \\
\hline & 11 & 12 & 13 & 11 & 12 & 13 & 11 & 12 & 13 & 11 & 12 & 13 & 11 & 12 & 13 & 11 & 12 & 13 & 11 & 12 & 13 & & \\
\hline Tragia brevipes & 5 & 4 & 3 & 1 & 2 & 2 & 3 & 5 & 4 & 1 & 2 & 2 & 1 & 2 & 3 & 2 & 1 & 3 & 2 & 3 & 2 & 53 & 7 th \\
\hline Nicotiana tabacum & 1 & 3 & 2 & 3 & 4 & 3 & 1 & 1 & 1 & 1 & 3 & 3 & 2 & 3 & 3 & 1 & 4 & 3 & 1 & 2 & 3 & 48 & 8th \\
\hline Dodonaea viscose subsp. angustifolia & 1 & 2 & 2 & 2 & 2 & 1 & 3 & 5 & 4 & 5 & 5 & 5 & 5 & 4 & 5 & 5 & 1 & 4 & 2 & 2 & 1 & 66 & $3 r d$ \\
\hline Albizia gummifera & 2 & 3 & 3 & 3 & 3 & 1 & 1 & 2 & 3 & 5 & 4 & 5 & 5 & 5 & 4 & 2 & 1 & 3 & 2 & 3 & 3 & 63 & 5 th \\
\hline Ensete ventricosum & 5 & 4 & 5 & 4 & 4 & 2 & 3 & 1 & 2 & 5 & 4 & 4 & 4 & 3 & 4 & 5 & 4 & 4 & 3 & 1 & 2 & 73 & $1 s t$ \\
\hline Ehretia cymosa & 1 & 2 & 3 & 5 & 4 & 1 & 5 & 3 & 3 & 3 & 3 & 3 & 3 & 3 & 3 & 1 & 1 & 2 & 3 & 2 & 2 & 56 & 6th \\
\hline Acacia etbaica & 1 & 3 & 2 & 4 & 2 & 1 & 5 & 1 & 4 & 5 & 5 & 4 & 5 & 4 & 3 & 2 & 2 & 3 & 2 & 3 & 3 & 64 & 4th \\
\hline Olea welwitschii & 1 & 2 & 3 & 4 & 4 & 5 & 3 & 1 & 3 & 5 & 4 & 5 & 4 & 4 & 4 & 2 & 3 & 3 & 4 & 4 & 4 & 72 & 2nd \\
\hline Total & & 73 & & & 80 & & & 69 & & & 93 & & & 82 & & & 62 & & & 60 & & & \\
\hline Rank & & 4 th & & & $3 r d$ & & & 5 th & & & $1 s t$ & & & $2 n$ & & & 6th & & & 7 th & & & \\
\hline
\end{tabular}

the passing of indigenous knowledge within families. Therefore, better conservational awareness by all community members is necessary to retain their own indigenous knowledge and to prevent the extinction of their medicinal plant resources.

\section{Comparison with previous ethnobotanical studies}

Moringa stenopetala (Baker f.) Cufod. was the most frequently used plant for amoeba, hypertension, and malaria treatment in the present study and similarly Asnake et al. [23] reported this plant use for malaria in Boricha district. Tamiru and Asalfew [41] reported for inflammation, wound, diabetes, eye disease, and headache treatment in Mirab Badwacho district. Tilahun et al. [56] reported this plant use mainly as vegetable for food. In Wonago district, this plant used for vomiting [3].

Nicotiana tabacum L. was the most frequently used plant and reported to be used against Snakebite, toothache, and headache in our study. Similarly, Yigezu et al.
[57] and Tamiru and Asalfew [41] mentioned this plant use for snake bite and toothache. This plant in five reports of study in Ethiopia stated its wide spread use in treatment of black leg, tick infestation, wound, leech, diarrhea, and gonorrhea [41, 42, 51, 57, 58].

Tragia brevipes Pax was used for evil eye, cancer, anthrax, and diarrhea in the present study, whereas it is used for babesiosis and abdominal pain in other study areas [26, 58]. Cucumis dipsaceus was documented for cough, cancer, and black leg treatment in the current study. Asnake et al. [23] and Sintayehu [27] reported this plant use for malaria, intestinal parasite, pneumonia, gonorrhea, and stomach problem.

Croton macrostachyus reported in the present study for the treatment of bone fracture, tuberculosis, gastritis, and goiter. Gonfa et al. [24] reported this plant only for tuberculosis purpose in Dale district. Yigezu et al. [57] found out the use of this plant for treatment of bloat in cattle. However, this plant was reported for the

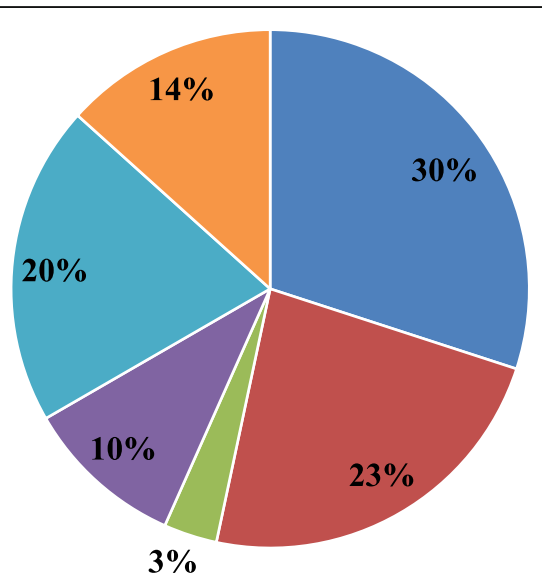

- Agriculture expansion

- Firewood

Charcoal

- Construction

Environmental degradation

Deforestation

Fig. 9 Threats to medicinal plants in the study area 
treatment of stomachache in Mirab Badwacho district [41], in Dale district [24], and Benna tsemay district [13]. Mirutse [46] and Melesse [44] mentioned the use of this plant for the treatment of snakebite. This plant was reported for the treatment of malaria in Boricha [23] and Amaro district [51]. Other studies reported this plant use for the treatment of wound [24, 51, 58].

Allium sativum L. was the most frequently used plant for abdominal pain, malaria, and mitch in the present study. This findings also agreed with the study conducted in Wonago district [3], Mirab Badwacho [41], Kembata [44], and Amaro district [12]. The plant product also has been used for other infections in upper respiratory tract [41]. Miruts et al. [52] and Mesfin et al. [12] reported this plant use for headache in Sheko and Amaro district respectively.

Aloe adigratana Reynolds. was a new Aloe species mentioned for the first time in the present study. It was reported in the present study for the treatment of skin disease and gastritis. The previous studies conducted in other area mentioned the use of Aloe spp. for cold and malaria treatment in Kembata [44] and Boricha district [23]. Rotheca myricoides (Hochst.) Steane \& Mabb. also known by the synonym Clerodendrum myricoides was reported to be used for mitch, cancer, and toothache treatment in the present study. Similarly, Yibrah [58] reported the use of this plant for teeth pain in Kochore district. Asnake et al. [23] reported the plant to be used against malaria in Boricha district.

Ensete ventricosum reported in the present study for placenta delay and weight gain in livestock and human. Unsimilarly, Reta [25], Giday et al. [52], and Andarge et al. [59] reported this plant for diarrhea, bone fracture, and tumor respectively. Olea welwitschii was commonly reported to be used for eye disease, headache, and gastritis in this study. Previous studies in Wayu Tuka and Tulu Korma district mentioned this plant for stomachache and gonorrhea disease treatment $[60,61]$.

Ricinus communis reported in the present study for the treatment of coughing, constipation, and swelling. However, Kassa [61] and Amenu [62] mentioned this plant for anthrax treatment in Tulu Korma and Ejaji district. Other studies in south western Ethiopia stated its use in treatment of rabies, sudden illness, blotting, wound, and mastitis [20, 60-63]. Eucalyptus globulus was the most frequently used plant and reported to be used for headache, mitch, stomachache, coughing, and common cold in our study. Similarly, it has been reported for common cold and influenza in Wayu Tuka district [60], Gimbi [64], and Dawuro zone [59]. Regassa [25] reported this plant use for malaria, typhoid, Ascarsis, and acute sickness in Hawassa city.

Nigella sativa L. was used for stomachache, gastritis, and headache in the present study. Similarly, this plant was reported for stomachache and headache in Hawassa city [25]. Others reported it for asthma, leprosy, and strepto thricosis in Wayu Tuka district [60] and Nekemet [65]. Acacia etbaica reported in the present study for the treatment of wound, cancer, and swelling. Similarly, Dinkissa et al. [66] mentioned this plant for wound treatment in Awash National park. However, Eneyew et al. [67] mentioned this plant for snakebite and evileye treatment in Fitche district.

Euphorbia abyssinica was reported for swelling, gastritis, malaria, and headache treatment in the current study. Similarly Abera [64] reported it for gastrointestinal disease in Ghimbi district. Ascaris, gonorrhea, warts, rabies, and venereal disease were the diseases mentioned on previous studies [64, 67]. Dodonaea viscose subsp. angustifolia was the most frequently used plant for evil eye and diarrhea in the present study. This findings disagree with the study conducted in other areas which stated the plant use for bone fracture, herpes, liver ailments wound, and acute sickness $[25,61,62,65]$.

According to the comparison of our findings with others ethnobotanical study in Ethiopia, novel plant uses of some medicinal plants were documented. Aloe adigratana, Tragia brevipes, Cucumis dipsaceus, Rotheca myricoides, Ricinus communis, and Dodonaea viscose subsp. angustifolia was completely novel use in our study area and never ever reported in other similar investigations. The pharmacological activity of these plants are novel findings that only known in this area for such medicinal purpose.

\section{Conclusions}

The results of the study revealed that there is high diversity of the medicinal plants in the Hawassa Zuria district. One hundred five medicinal plant species were documented to treat 61 human and livestock ailments. Stomachache, headache, malaria, gastritis, mitch, amoeba, goiter, tuberculosis, gonorrhea, and urine problems were frequently occurring human ailments, whereas wounds, ticks, swelling, anthrax, evil eye, and 'gadanesa' were common livestock ailments. This indicates that local people depend on indigenous knowledge to prevent various human and livestock ailments.

In the study area, major knowledge differences were found among different social groups. Male informants had more knowledge than females. Older informants above 50 years of age were more knowledgeable than the young between 20 and 35 years and adult informants between 36 and 50 years. Informants who attended elementary school had more knowledge than those who were illiterate.

The main threats to medicinal plants in the Hawassa Zuria district were deforestation, agricultural expansion, 
and overexploitation. The medicinal traditional knowledge gap between the older and young generations has also impacted the loss of indigenous knowledge. Therefore, there should be mentoring programs for local people in the study area to conserve their indigenous knowledge resources and prevent the extinction of their medicinal plants.

Conservation of endangered endemic medicinal plants through in vitro and ex vitro propagation should be developed to protect the extinction of medicinal plants. Furthermore, the current documented information on the medicinal plants of the Sidama people can be used as baseline data for future studies of pharmacologically important medicinal plants and for phytochemical investigations.

\section{Additional files}

Additional file 1: Table S1. Semi-structured questionnaire, research questions and hypothesis (DOCX $16 \mathrm{~kb}$ )

Additional file 2: Table S2. List of plant families. (DOCX $18 \mathrm{~kb}$ )

Additional file 3: Table S3. List of diseases and number of plant species (DOCX $18 \mathrm{~kb}$ )

Additional file 4: Table S4. Sociodemographic details of the respondents in the Hawassa Zuria district. (DOCX $15 \mathrm{~kb}$ )

Additional file 5: Table S5. Other uses of medicinal plants in the study area. (DOCX $15 \mathrm{~kb})$

\section{Acknowledgments \\ The authors would like to acknowledge the Wondo Genet Agricultural Research Center (WGARC), the Wondo Genet College of Forestry and Natural Resource, and the National Herbarium of Addis Ababa University for supporting this research by allowing car services, accommodation, and laboratory use. We are very grateful to the study participants who shared their knowledge of the use of medicinal plants. The authors would like to acknowledge Dr. Ermias Lulekal and related staff members, Mr. Muluken Philipos and related staff members, Mr. Eyob Ulcha and Mr. Melkamu Hordofa for their sincere and unreserved support in Ethiopia. Last but not least, grateful acknowledgment of assistance goes to Mr. Homervergel Ong for his support during the field trip to Ethiopia.}

\section{Ethics approval and consent participate}

Permission to conduct the ethnobotanical study was obtained from the district administration and village office in the study area. The purpose of the study was explained to all participants, and they agreed to provide information. Identification and deposit work collaboration with the National Herbarium of AAU were also allowed according to official letters of consent.

\section{Funding}

The authors would like to express their deepest gratitude to the National Institute for International Education (NIIED) for the Government of Korean Scholarship (GKS) as financial support with which to conduct this research.

\section{Availability of data and materials}

The authors declare that all other data supporting the findings of this study are available within the article and its supplementary information files.

\section{Authors' contributions}

BN designed the research survey, carried out a field survey, collected and analyzed the data, and wrote the manuscript as the major contributor of the study. MW helped with species identification and confirmation at the National Herbarium of Addis Ababa University. YK reviewed the analyzed data and gave critical comments. All authors have read and approved of the final manuscript.
Consent for publication

Not applicable.

\section{Competing interests}

The authors declare that they have no competing interests.

\section{Publisher's Note}

Springer Nature remains neutral with regard to jurisdictional claims in published maps and institutional affiliations.

\section{Author details}

'Department of Life Science and Multidisciplinary Genome Institute, Hallym University, Chuncheon 24252, Republic of Korea. ${ }^{2}$ Ethiopian Institute of Agricultural Research, P.O. Box 2003, Addis Ababa, Ethiopia.

Received: 12 November 2018 Accepted: 17 April 2019

Published online: 24 May 2019

\section{References}

1. WHO. Regulatory situation of herbal medicines. A worldwide review. Geneva: World Health Organization; 1998. p. 1-5.

2. Lucy H, Edgar JD. Medicinal plants: a reemerging health aid, division of life sciences UNESCO; 1999.

3. Mesfin F, Demissew S, Teklehaymanot T. An ethnobotanical study of medicinal plants in Wonago woreda, SNNPR, Ethiopia. J Ethnobiol Ethnomed. 2009;5:1-28.

4. Abebe D. In: Zewdu M, Demissie A, editors. The role of medicinal plants in healthcare coverage of Ethiopia, the possible benefits of integration. 6-21 in conservation and sustainable use of medicinal plants in Ethiopia. Proceedings of the National Workshop, 28 April-01 May 1998. Addis Ababa: Institute of Biodiversity Conservation and Research; 2001.

5. Nguta JM, Mbaria JM, Gakuya DW, Gathumbi PK, Kiama SG. Antimalarial herbal remedies of Msambweni, Kenya. J Ethnopharmacol. 2010;128(2): 424-32.

6. Central statistical agency (CSA). Ethiopian demographic and health survey. Addis Ababa: Central Statistical Agency; 2006.

7. Central statistical agency (CSA). Ethiopian demographic and health survey. Addis Ababa: Central Statistical Agency; 2007.

8. Anteneh B, Zemede A, Sebsebe D, Negussie FB. Medicinal plants potential and use by pastoral and agro pastoral communities in Erer Valley of Babile woreda, eastern Ethiopia. J Ethnobiol Ethnomed. 2012;8:42.

9. Mirutse G. Medicinal plant of the Bench, Meinit and Sheko cultural groups in Ethiopia with emphasis on use diversity, informant consensus, abundance and habitat. Ph. D Dissertation. Addis Ababa: Addis Ababa University; 2007.

10. Giday M, Asfaw Z, Elmqvist T, Woldu Z. An ethnobotanical study of medicinal plants used by the Zay people in Ethiopia. J Ethnopharmacol. 2003:85:43-52.

11. Desalegn D. Economic value of medicinal plants in Ethiopia, a case study. Paper prepared for the National Workshop on Biodiversity Conservation and Sustainable Use of Medicinal Plants In Ethiopia. April 26-May 1, 1998. Addis Ababa. p. 1997.

12. Getu A. Plant diversity and ethnobotany of medicinal and wild edible plants in Amaro district of Southern nations, nationalities and peoples region and Gelana district of Oromia region, Southern Ethiopia. PhD Dissertation. Addis Ababa: Addis Ababa university; 2017.

13. Assegid A, Tesfaye A. Ethnobotanical study of wild medicinal trees and shrubs in Benna Tsemay District, southern Ethiopia. JSD. 2014;2(1):17-33.

14. Mersha A, Zemede A, Ensermu K. Ethnobotanical study of wild edible plants in Burji district, Segan area zone of southern nations, nationalities and peoples region (SNNPR), Ethiopia. J Ethnobiol Ethnomed. 2016;12:1-32.

15. Behailu $B$, Temesgen A. Ethnobotanical value of medicinal plant diversity in Cheha district, Guraghe zone, southern nations, nationalities and peoples (SNNPR) of Ethiopia. Academic Journals J Med Plants Res. 2017;11(28):445-54.

16. Emiru B, Ermias A, Wolde M, Degitu E. Management, use and ecology of medicinal plants in the degraded dry lands of Tigray, Northern Ethiopia. J Med Plants Res. 2011;5(3):309-18.

17. Getachew A, Zemede A, Zerihun W. Ethnobotany of wild and semi-wild edible plants of Konso ethnic community, South Ethiopia. Ethnobot Res Appl. 2013;11:121-41. 
18. Tesfaye B, Sebsebe D, Zemede A. An ethnobotanical study of medicinal plants used by local people in the lowlands of Konta special Woreda, southern nations, nationalities and peoples regional state, Ethiopia. J Ethnobiol Ethnomed. 2009:4(1):107-22.

19. Mulugeta K, Erchafo M. Indigenous knowledge on use of medicinal plants by indigenous people of Lemo District, Hadiya zone, Southern Ethiopia. Int J Herb Med. 2017:5(4):124-35.

20. Berhane K, Tinde VA, Laurentius JG, Zemede A. Use and management of traditional medicinal plants by Maale and Ari ethnic communities in Southern Ethiopia. J Ethnobiol Ethnomed. 2014;10:1-46.

21. Takele B. Ethnobotanical study of medicinal plants in Wolaita zone, Southern Ethiopia. J Health Med Nursing. 2018;48:2422-8419.

22. Asfaw T, Tarekegn $\mathrm{H}$. Assessment of the indigenous knowledge and use of traditional medicinal plants in Wolaita zone, Southern Ethiopia. IJMPNP. 2017;3(1):16-22

23. Asnake S, Teklehaymanot T, Hymete A, Erko B, Giday M. Survey of medicinal plants used to treat malaria by Sidama people of Boricha District, Sidama Zone, South Region of Ethiopia. Evid Based Complement Alternat Med. 2016;2016(ID96901644):9.

24. Gonfa K, Tefaye A, Ambachew D. Indigenous knowledge on the use and management of medicinal trees and shrubs in Dale district, Sidama zone, Southern Ethiopia. A journal of plants, people and applied research. Ethnobot Res Appl. 2015;14:171-82.

25. Reta R. Assessment of indigenous knowledge of medicinal plant practice and mode of service delivery in Hawassa city, Southern Ethiopia. J Med Plant Res. 2013;7(9):517-35.

26. Tekle Y. Medicinal plants in the ethno veterinary practices of Bensa Woreda, Southern Ethiopia. Open Access Library Journal; 2015.

27. Sintayehu T. An ethnobotanical study of medicinal plants in Wondo genet natural forest and adjacent kebeles, Sidama zone, SNNP region, Ethiopia. Thesis. 2011.

28. Edwards $\mathrm{S}$. The ecology and conservation status of medicinal plants on Ethiopia. What do we know? pp. 46-55. In: Zewdu M, Demissie A, editors. Conservation and sustainable use of medicinal plants in Ethiopia, Proceedings of National Workshop on Biodiversity Conservation and Sustainable use of medicinal plants in Ethiopia. Addis Ababa: Institute of Biodiversity Conservation and Research; 2001.

29. Zone Sidama Finance and Economic Development Bureau (SZFEDB). Population projection and socio economic profile of Sidama. Magazine, vol. 2. Ethiopia: SNNPR; 2003.

30. Heinrich M, Ankli A, Fre B, Weimann C, Sticher O. Medicinal plants in Mexico: healers consensus and cultural importance. Soc Sci Med. 1998;47:1859-71.

31. Ayyanar M, Ignacimuthu S. Traditional knowledge of Kani tribals in Kouthalai of Tirunelveli hills, Tamil Nadu, India. J Ethnopharmacol. 2005; 102(2):246-55.

32. Philips O, Gentry AH, Reynel C, Wilkin P, Galvezdurand BD. Quantitative ethnobotany and Amazonian conservation. Conserv Biol. 1994;3:350-61.

33. Canales M, Hernandez T, Caballero J, Romo de Vivar A, Avila G, Duran A, Lira R. Informant consensus factor and antibacterial activity of the medicinal plants used by the people of San Rafael Coxcatlan, Puebla, Mexico. J Ethnopharmacol. 2005;97:429-39.

34. Friedman J, Zohara Y, Amotz D, Palewitch D. A preliminary classification of the healing potential of medicinal plants, based on a rational analysis of an ethnopharmacological field survey among Bedouins in the Negev Desert, Israel. J Ethnopharmacol. 1986;16:275-8.

35. Kent M, Coker P. Vegetation description and analysis: a practical approach. London: Belhaven Press; 1992.

36. Martin GJ. Ethnobotany; a method Manual Chap mart and Hall. London: Earthscan publications; 1995. p. 267.

37. Cotton CM. Ethnobotany: principles and applications. Chichester: Wiley; 1996. p. 347-74.

38. Lulekal E, Zemede A, Ensermu K, Patrick VD. Ethnomedicinal study of plants used for human ailments in Ankober District, north Shewa zone, Amhara region, Ethiopia. J Ethnobiol Ethnomed. 2013;9:63.

39. Teferi F, Teferi G, Kaleab A, Tsige GM. Ethnomedical survey of Berta ethnic group Assosa zone, Benishangul-Gumuz regional state, mid-west Ethiopia. J Ethnobio Ethnomed. 2009;5:14.

40. Hunde D, Asfaw Z, Kelbessa E. Use and management of ethnoveterinary medicinal plants by indigenous people in 'Boosat', Welenchiti area. EJBS. 2004;3:113-32.

41. Tamiru T, Asalfew D. Ethnobotanical study of medicinal plants of Mirab Badwacho district, Ethiopia. J BioSci Biotechnol. 2016;5(2):151-8.
42. Ketema T, Etana D, Spiridoula A, Adugna T. Ethno-medicinal study of plants used for treatment of human and livestock ailments by traditional healers in south Omo, Southern Ethiopia. J Ethnobiol Ethnomed. 2013;9:32.

43. Habtamu A, Mulatu O, Tsdeke L. Traditional medicinal plants utilization, management and threats in Hadiya zone, Ethiopia. J Med Plant Studies. 2014.

44. Melesse M, Sileshi N, Tamirat B. An ethnobotanical study of medicinal plants of the Kembatta ethnic group in Enset-based agricultural landscape of Kembatta Tembaro (KT) zone, Southern Ethiopia. Asian J Plant Sci Res. 2015;5(7):42-61.

45. Gidey M. Assessment of traditional medicinal plants in Endrta District, South-Eastern Tigray, Northern Ethiopia. Afr J Plant Sci. 2010;4:255-60.

46. Giday M, Asfaw Z, Woldu Z. Medicinal plants of the Meinit ethnic group of Ethiopia; an ethnobotanical study. J Ethnopharmacol. 2009;124:513-21.

47. Teklehaymanot T. Ethnobotanical study of knowledge and medicinal plants use by the people in Dek Island in Ethiopia. J Ethnopharmacol. 2009;124:69-78.

48. Gedif $\mathrm{T}$, Hahn $\mathrm{H}$. The use of medicinal plants in self-care in rural central Ethiopia. J Ethnopharmacol. 2003;87:155-61.

49. Lulekal E, Kelbessa E, Bekele T, Yineger H. An ethnobotanical study of medicinal plants in Mana Angetu District, Southeastern Ethiopia. J Ethnobiol Ethnomed. 2008:4:1-10.

50. Tilahun T, Mirutse G. Ethnobotanical study of medicinal plants used by people in Zegie peninsula, Northwestern Ethiopia. J Ethnopharmacol. 2006;3:1-12.

51. Mesfin F, Seta T, Assefa A. An ethnobotanical study of medicinal plants in Amaro Woreda, Ethiopia. Ethnobot Res Appl. 2014;12:341-54.

52. Giday M, Asfaw Z, Woldu Z. Ethnomedical study of plants used in Sheko ethnic group of Ethiopia. J Ethnopharmacol. 2010;132:75-85.

53. Gedif T, Hahn H. Herbalists in Addis Ababa and Butajira, Central Ethiopia: mode of service delivery and traditional pharmaceutical practice. EJHD. 2002;16:191-7.

54. Balemie K, Kelbessa E, Asfa Z. Indigenious medicinal plant utilization, management and threats in Fentalle area,Eatern Shewa, Ethiopa. EJBS 2004; 3:37-58.

55. Giday M, Asfaw Z, Woldu Z, Teklehaymanot T. Medicinal plant knowledge of the Bench ethnic group of Ethiopia; an ethnobotanical investigation. J Ethnobiol Ethnomed. 2009;5:34.

56. Teklehaymanot T, Giday M. Quantitative ethnobotany of medicinal plants used by Kara and Kwego semi-pastoralist people in lower Omo River Valley, Debub Omo zone, southern nations, nationalities and peoples regional state, Ethiopia. J Ethnopharmacol. 2010;130:76-84.

57. Yigezu Y, Demissew BH, Wubeante YA. Ethnoveterinary medicines in four districts of Jimma zone, Ethiopia: cross sectional survey for plant species and mode of use. BMC Vet Res. 2014;10:76.

58. Yibrah T. An ethno veterinary botanical survey of medicinal plants in Kochore district of Gedeo zone, southern nations nationalities and peoples regional state (SNNPRs), Ethiopia. JSIR. 2014;3(4):433-45.

59. Andarge E, Shonga A, Agize M, Tora A. Utilization and conservation of medicinal plants and their associated indigenous knowledge (IK) in Dawuro zone: an ethnobotanical approach. Int J Medicinal Plant Res. 2015;4:330-7.

60. Megersa M, Asfaw Z, Kelbessa E, Beyene A, Woldeab B. An ethnobotanical study of medicinal plants in Wayu Tuka District, East Welega zone of Oromia regional state, West Ethiopia. J Ethnobiol Ethnomed. 2013;9:68.

61. Kassa Z, Asfaw Z, Demissew S. Ethnobotanical study of medicinal plants used by the local people in Tulu korma and it's surrounding areas of Ejere district, Western Shewa zone of Oromia regional state, Ethiopia. J Med Plants Stud. 2016;4(2):24-47.

62. Amenu E. Use and management of medicinal plants by indigenous people of Ejaji area (Chelya Woreda) West Shoa, Ethiopia: An ethnobotanical approach. MSc Thesis. Addis Ababa: Addis Ababa University; 2007.

63. Romha G, Dejene TA, Telila LB, Bekele DF. Ethnoveterinary medicinal plants: preparation and application methods by traditional healers in selected districts of southern Ethiopia. Veterinary World. 2015;8(5):674-84.

64. Abera B. Medicinal plants used in traditional medicine by Oromo people, Ghimbi District, Southwest Ethiopia. J Ethnobiol Ethnomed. 2014;10:40.

65. Suleman S, Alemu T. A survey on utilization of ethnomedicinal plants in Nekemte town, East Wellega Oromia region, Ethiopia. J Herbs Spices Med Plants. 2012;18(1):34-57.

66. Dinkissa B, Getaneh G, Kebenu F. Indigenious utilization and management of useful plants in and around Awash National Park, Ethiopia. J Plant Biol Soil Health. 2016:3:1

67. Eneyew A, Asfaw Z, Kelbessa E, Nagappan R. Ethnobotanical study of traditional medicinal plants in and around Fiche District, Central Ethiopia. Curr Res J Biol Sci. 2014;6:154-67. 